NATURE STUDIES ROBERT R.MOLEOD

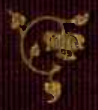


961 
Aushis Cpy

Presented

tomy cnisin ine Esther b ofana RTMdear Oet $20^{\prime \prime} 190$<smiles>CCC(C)C(C)(C)C(C)(C)C</smiles> 




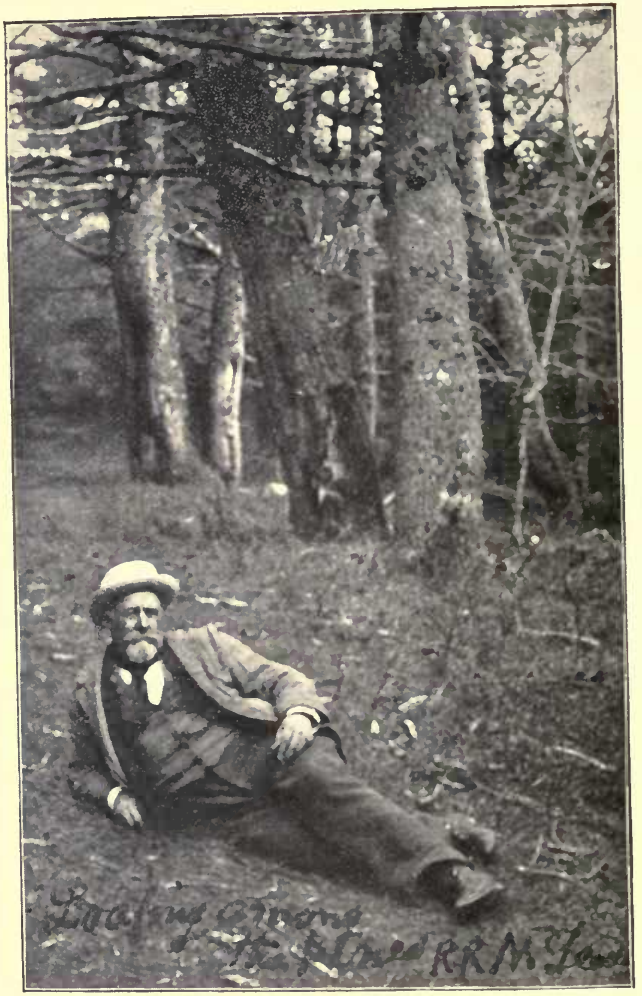




\section{In the Acadian Land}

NATURE STUDIES

BY

ROBERT R. MCLEOD

1,

BOSTON

BRADLEE WHIDDEN

1899

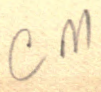


Copyright, 1899, BY

ROBERT R. McLEOD 
DEDICATED

To

\section{Agurs Sophia}

MY

WIFE 



\section{INTRODUCTION.}

IT has pleased my fancy and suited my purpose to locate the following chapters on the Molega Road. To find it one must go to the northern district of Queens County, Nova Scotia. It connects a small gold-mining community with other villages. Only a distance of six miles through barren and brush, and meadow, past fringes of old woods, and swamps of spruce and maple, over ledges, two brooks and a river. A very commonplace stretch of new road, but in passing over it several thousand times, in all seasons and all weathers, it became more charming, more to be seen, and learned, and admired. It would be a pleasant employment for me to fill volumes with the unwritten diaries of these journeys. However, I celebrate them with this little book, in the hope some readers will become interested, and thereby life enlarged and curiosity stimulated to know more of the wonderful world so easily accessible to all dwellers in the country, and that, too, without money and without price.

Robert R. McLeod.

Brookfield, Queens County, N. S., 1899. 



\section{CONTENTS.}

PAGE

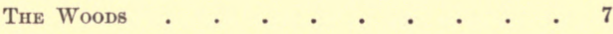

A Butterfly . . . . . . . . . 23

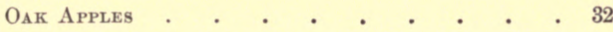

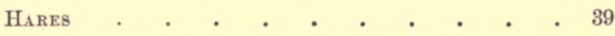

WEAsels . . . . . . . . . . . 49

SpIDERs . . . . . . . . . . 56

A Gold Mine . • . . . . . . . 63

Lunch By the Brookside . . . . . . 74

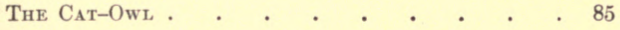

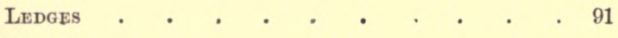

Bats . + . , . . . . 98 
CONTENTS.

PAGE

By the RIVERSIDE . • • • • • • . 105

The Red Squirrel. . • • • . • . 114

BIRDS. . . . . . . . . . . 127

Micmac Indians $\quad . \quad$. $\quad . \quad$. $\quad . \quad 141$

Puff-Balls, Toadstools and that Sort of Thing . 156 


\section{THE WOODS.}

"THE woods were made for the hunters of dreams,

The brooks for the fishers of song ;

To the hunters who hunt for the gunless game

The streams and the woods belong.

There are thoughts that moan from the soul of the pine And thoughts in a flower-bell curled;

And the thoughts that are blown with the scent of the fern Are as new and as old as the world." - Foss.

$\mathrm{O}^{\mathrm{N}}$ first impression one might say that there are no woods worth consideration on the Molega Road. It is quite true that there are no trees desirable for lumber or ship-timber; there are no dusky forest-aisles, but for all this lacking there are woods crowded with objects of interest, and replete with subtle beauty. An acquaintance of Turner, the great landscape painter, once stood by him while he sketched a scene. As he proceeded to complete the work his companion remarked,

"But, Mr. Turner, I do not see in the landscape the beauty you have put in your picture."

"Don't you wish you could see it?" was the artist's reply. 
It depends upon what taste and love of nature that one brings to the landscape or the woods, whether he will discover beauty therein. If the woods are only to be looked upon as an assemblage of trees serviceable for saw-logs, shiptimber, cordwood, harrow-crotches and sled-runners, then this is the view of the browsing moose. $\mathrm{He}$ knows the locality as a feeding-ground and shelter. We do not blame him for not looking deeper, because his natural capacity goes no farther. But man has finer endowments, that, if rightly cultivated and properly used, enable him to appreciate the beauty and diversity and infinite resources of nature. Even the great works of men's minds and hands are worthy of study and admiration. How much more worthy are the products of the master mind that brings forth suns in galaxies, and finds room in the commonest toadstool to exercise a skill and power that passes our comprehension. It is the proper part of education, at home and in the school, to draw out these higher qualities of the mind, that show themselves in the eager curiosity and enthusiasm of childhood and youth. Alas, that our methods are so well calculated to suppress the opening buds of higher promise! Alas that the "life star" that was born with us "fades into the light of common day" and the 
vision by which we were attended vanishes forever !

We will return to a consideration of trees and forests. The most unpromising feature in this direction one soon comes upon after entering the road. Here and there among the hoop-pole wire birch are dead pines - victims of fires that killed them many years ago. They are too crooked, and crotched, and beset with strong limbs and knots, to serve for lumber; so they remain, scattered, gaunt, bare and gray, reaching out long naked arms defiantly to all winds. They are merely touched with decay; only the "sap," or last growth, an inch or two in thickness, has become tattered and weather-stricken ; all the rest is sound and strong. These pines are unlike those of the same species that grow in the thick forests of their kind. In those conditions there is hard competition for room to live. There thousands of seeds of pine sprout and begin to grow within a small area. It is simply impossible for them all to reach maturity, or even arrive to a height of a few inches. They will be thinned out by natural selection; that is to say, those that are best fitted to continue will live. The advantage may be small, a mere bit more light or a better rootage or sounder seed, but on these points their lives 
depend. "Many are called but few are chosen," - that is the universal law of all life. The straightest saplings with no more limbs than are needed will get their tops into the sunshine and their roots into good ground, and become great trees, smooth and clean. The closer together they grow the straighter they will be, and less knots and limbs. Scrubby specimens beginning life there, are doomed to decline and meet an early death. In the forests, all are sheltered from the force of the wind; they stand by each other right loyally. But out on the open barren here and there a wind-wafted pine seed germinates and slowly grows. There is no lack of sunshine, there is no serious competition ; but the soil is not friendly: they are underfed. The roots grapple with obstructing rocks, fierce winds wrestle with the sturdy branches and resisting trunk. In the long run of a century such a tree eomes to plainly show the marks of its struggles with the elements. The grain of the wood is close, and hard, and twisted. Where the limbs join the trunk there are encircling bosses formed of wood wherein the grain or fibre is wound round and round, in sturdy self-defence of the winds; for on these branches are the lungs, and thereby hangs the life. With this understanding about them, these dead scrub. 
pines are not without a living interest, and fancy pleasantly invests them with more than the eye can see, and Science lingers over them, knowing right well they can teach her many a lesson worth knowing.

Our Molega Road, woods, are but the straggling fringes of larger tracts that run back into low hills and swamps. They are not growths where some particular species lords it over all, but many kinds struggle for a foothold. Spruce and fir, birches, oaks, maples, pines, hemlock, and beech jostle each other in thickets. These deeper solitudes, where a human footstep does not pass perhaps in years, although not more than a couple of miles from houses, are the abodes of squirrels, and rabbits, and mice, and wildcats, and foxes. Birds are not abundant in such retreats, but there are always enough to enliven the scene with their presence.

Leaving local considerations, we will accept the invitation that beckons us to a wider discussion of this theme. Let me remark that it can be shown that life existed on this earth many hundred thousand years before there was a tree. The earliest water-made or sedimentary rocks have preserved the records of those times. In them are the remains and impressions of seaweeds, lichens, club-mosses, ferns and other 
forms of vegetation, wherein there was no blossom, and therefore no fruit. The first trees were giant club-mosses and ferns; their trunks are imbedded in coal mines, and they have become coal. 'Trees that bear fruit came late in the world's history. They are products of evolutionary action, whereby creation proceeds to higher and more complex forms. Our trees all have pedigrees that run back into the lowest and earliest vegetable life. They have been a weary while in the making, as we reckon time. They have all been elected by processes that operated without sentiment, and permitted only the fittest to survive. They have all come forth out of great tribulation, and every outward feature and every inward disposition and tendency of each species is either a scar of conflict, a plan for propagation, a vestige of ancestry, or a taint of on-coming dissolution. The dimensions when full-grown, the nature of the grain, the peculiarities of the bark, the shape of the leaves, the contour of the foliage, are all what they are because of the experiences of the species and its ancestries. To deny this statement would be to ignore the plainest truths. If any reader feels that the Creator is not recognized in this way then let him consider how a tree is not called into existence to-day, but grows slowly from a 
seed; but that is the manner in which the Creator operates. Because an oak-tree, for instance, was not suddenly called into existence loaded with leaves and acorns, but, through millions of years, has been produced, is none the less a creative act.

Our vast ages are God's days. The computations of his calendar, are not to be fitted into our petty almanacs. The philosophy of evolution clothes the Deity with greater grandeur than the theory of sudden creations permits. It enables us to see not only the plan or design of the structure, but its upbuilding; not only the finished product, but the various steps of its development. We are not merely moved to throw up our hands in pious admiration of the completed object, be it tree or man, but we are moved to reverent wonder, or religious awe when viewing the marvellous transformations through which it was guided to completion. When we study the evolution of any kind of tree we are soon in the midst of a wonderland of captivating charms. We thus enter the laboratory of nature; we see not only the moving wheels, but the "life within the vast machine;" we may even realize a real presence in leaf, and blade, and bloom, making and unmaking, till - 
"What it hath wrought is better than hath been; Slow grows the splendid pattern that it plans Its wistful hands between."

An evolutionist may fail to believe in God, and there are irreverent astronomers, but the God of an evolutionist is not a shadowy possibility, nor an absentee deity from this world, but an indwelling presence, not identical with material nature, but no material world apart from him. He may say for himself,

"I am the mote in the sunbeam, and I am the burning sun.

'Rest here,' whispers the atom; I call to the orb, 'Roll on !' I am the blush of the morning and I am the evening's breeze I am the leaf's low murmur, the swell of the terrible seas;

I am the breatl of the flute, I am the mind of inan;

Gold's glitter, the light of the diamond, the sea-pearl's lustre wan;

I am what was, will be, creation's ascent and fall ;

The link, the chain of existence, beginning and end of all."

We are not heedful enough of our trees. When Abraham bought the field and the cave of Machpelah "all the trees that were in the field, that were in all the borders round about, were made sure ;" and he did not cut them down, but sat under their shade, where aforetime he had entertained angels. A treeless world would be a manless world, so far as this planet is concerned. The forests can do better without man, but we could not do without them. Not only do 
we depend upon them for wood of all kinds, but without them streams and springs would become dry, rainfalls would quickly run away and evaporate, where now the water is retained in cool shades and slowly fed to the sources of great rivers. With the disappearance of trees would go great troops of birds that feed on the insects or fruits that are found on them.

Trees are associated with the history of our race more intimately than any other natural feature of the earth. They have played an indispensable part in the creation of mankind. If there had been no fruit-trees there would never have been evolved an animal to climb them, and help himself to the concentrated foods. No great advancement of brain could be reached on other lines. But the hands of monkeys, apes and men are all of the same pattern. Human hands were evolved before our ancestors were human. This marvellous instrument was formed in the long run for climbing, and swinging from branch to branch, for breaking the shells of nuts, and all purposes for which apes use it to-day. The hand was the pioneer of our race. It became the servant of the brain. Slowly released from the drudgery of bearing the body, it entered the service of the mind. And the first of our ancestors who used his fingers to fasten a 
handle to a stone to form a club, inaugurated without ceremonies, the opening of the epoch, wherein mind was to measure itself with muscles and claw's and win the dominion of the world, and analyze the light of sun and stars. The first men were forest dwellers; their homes were amid tropical trees, where their ancestors had dwelt for unknown ages. The Bible has it, that Adam was placed in a lovely spot, where the Lord God had made to grow every tree that is "pleasant to the sight and good for food." The sight was to be gratified as well as the appetite. The love of beauty was considered before the demand for food. "Trees pleasant to the sight" shows that the Creator expected a responsive admiration on the part of man. He was not to exclaim first of all, what delicious-looking berries! but, what beautiful trees! - sentiment first and stomach afterwards. If it be contended that we cannot live on sentimental considerations, I reply that neither can we live on "bread alone." Eating and drinking are mere coal-heaving operations, to enable us to make a voyage of life wherein the highest qualities may come to growth. If that be not the truth, then far better would it have been, that man never advanced beyond the stage where the satisfaction of life was in the gratification of appetite. The 
man who goes through the woods and sees nothing in them but lumber, ship-timber, and cordwood has missed a princely birthright. But people find a charm in the woods who are not moved by beauty. Even city born and bred men and women discover an indefinable something in the unspoiled forests that is restful and healing to body and mind; they come there to a patrimony all their own; there old instincts are satisfied.

Says the poet, "The groves were man's first temples." They were also his first homes ; there he made his first rude roofs, and there under the lowly thatch the family life began, that will not be complete till a recognition of human brotherlıod silences the last cannon and sheaths the last sword. So deep-rooted and mysterious has been the love of this old home that men of antiquity everywhere worshipped trees, and it still continues in India and other Oriental lands. The sacred Bo-tree of Anuradhopura, in Ceylon, is visited by many thousand pilgrims every year, and happy is he who bears away a leaf that has dropped within his reach. During two thousand one hundred and thirty years Buddhists have held this to be a sacred tree, grown from a scion or shoot of a tree under which the "Blessed One," the founder of Buddhism, contemplated 
and wrought out by prayer and penance a royal road for suffering man, and more than three hundred million people eall him the "Blessed One" after the lapse of all these centuries. The Bible has frequent allusions to sacred trees and groves. It has a tree of knowledge of good and evil, on which grew the fateful "fruit of finest colors, mixed ruddy and gold." It was Abralram who "planted a grove in Beersheba and called there on the name of the Lord." Josephus, the Jewish historian, tells us that the burning bush in which Moses saw Jehovah's presence was a sacred tree before that event. It was a natural stick that Moses had in his hand, and was afterwards used for miraculous purposes as a magic rod. Hezekiah cut down the sacred groves, and his great-great-grandson cut down another growth in his effort to root out the foreign worship that clung to the forests.

The Greeks had sacred groves, and many of their gods had trees sacred to them in popular estimation. Thus the oak fell to Zeus, the greatest of all, to Apollo the laurel, to Athene the olive, etc. The ancient Germans worshipped in groves. The Celtic druids of France and England, Ireland and Scotland had their religious sanctuaries in the deep forests. The Norsemen, of Norway and Sweden, told wondrous 
stories of a mythical ash-tree. It is related in their sagas that "it is the largest and best of trees; its branches spread all over the world and reach up over the heaven," and, much more, that all had a meaning in the "brave days of old," to these our rugged ancestors.

It is by no accident that the trees and groves and woods play so large a part in human history, that they are interwoven with myths and legends and religious rites. Through poetry, ancient and modern, runs always the same echo of an unwritten forest hymn. The Hebrew prophets extol the beauties of the cedars, and the virtues of the "Balm of Gilead." "And the glory of Lebanon shall come unto thee, the fir tree and the box tree together, to beautify the place of my sanctuary." This universal sentiment of mankind finds a voice in the poets; Bryant exclaims :

"Father, thy hand

Hath reared these venerable columns; thou

Did'st weave this verdant roof!"

Longfellow writes :

"There is a spirit in these quiet woods;

With what a tender and impassioned voice

It fills the nice and delicate ear of thought.

Hence gifted bards

Have ever loved the calm and quiet shades; For them there was an eloquent voice in all The sylvan pomp of woods." 
In her sonnet on "Trees" Mrs. Hemans writes thus :

“And ye are strong to shelter! All weak things, All that need a home and covert, love your shade!"

Says Cowper of the "Woods":

"Meditation here

May think down hours to moments. Here the heart

May give a useful lesson to the head

And learning wiser grow without his books."

Emerson quits the city for the country and celebrates his escape in a poem, in part running thus :

“Good-by, proud world, I'm going home;

I go to seek my own hearthstone

Bosomed in yon green hills alone;

A secret lodge in a pleasant land, Whose groves the frolic fairies planned$\mathrm{Oh}$, when I am safe in my sylvan home I mock at the pride of Greece and Rome! And when I am stretched beneath the pines, Where the evening star so holy shines, I laugh at the lore and pride of man, At the sophist's school and the learned clan; For what are they all in their high conceit, When man in the bush with God may meet?"

Swinburne, in his "Palace of Pan," touches this inspiring theme in forceful and moving verse. Here follows a stanza or two that will indicate their quality and merit to those who 
feel the mystic charm and moving beauty that inspire his muse :

"Far eastward and westward the sun-colored lands

Smile warm as the light on them smiles;

And statelier than temples upbuilded by hands,

Tall column by column the sanctuary stands,

Of the pine forest's inflnite aisles.

"A temple whose transepts are measured by miles,

Whose cliancel has morning for priest.

Whose floor-work the foot of no spoiler defiles, Whose musical silence no music beguiles,

No festival limits its feast."

In a true sense the forests are sacred. They may well have been "God's first temples." They are not to be wantonly injured nor lightly destroyed. They have come down to us from other generations, and with a reasonable use of their products we are bound in duty to deliver them to our successors. Our oldest oaks and hemlocks were no mere saplings when Columbus discovered America. It takes many centuries to produce the great trees in our own forests, to anchor them fast by the gnarled and tangled clutch of sturdy rootage, to drape them in bearded lichens till they stand "like Druids of eld," to garnish the bark with mosses and decorate the dead with the finery of elfin fungus and wreaths of living ferns. Long centuries it 
took to win the confidence of the daintiest flowers and draw them from the fierce struggle for existence with contending species that must have the glaring sunshine or perish from the earth. These forests became an asylum for delicate forms that could not hold their own outside with coarser species. No thistles nor docks, nor daisies nor buttercups, nor any of their clans ever grow and bloom in leafy mould or mossy tussock of our deeper woods. Nestled there

"Is beauty, such as blooms not in the glare Of the broad sun. The delicate forest flower With scented breath, and looks so like a smile, Seems, as it issues from the shapeless mould, An emanation of the indwelling Life, A visible token of the upholding Love, That are the soul of this wide universe." 


\section{A BUTTERFLY.}

\footnotetext{
"So much to learn! Old Nature's ways

Of glee and gloom with rapt amaze, To study, probe and paint - brown earth, Salt seas, blue heavens, the tilth and dearth, Birds, grasses, trees, the natural things That throb or grope, or poise on wings."
}

THE largest of our butterflies are out in 1 great force to-day. I refer to yellow and black species, mostly yellow. The name in books, by which students know them all over the world, is Papilio turnus. On the edges of the muddy puddles in the road many of them are settled down for something to drink. Not one person out of a dozen knows how they do that. If you take one of them in your hands and examine his head you will find under his chin a threadlike, close coil. If you take a pin or a needle and pull it out the length will be found to be about one inch. This instrument is hollow; it is used principally for sucking honey from blossoms. But there is no accounting for taste ; and here are these beautiful creatures so delighted and intoxicated with the washings 
of the road that one may pick them up with thumb and fingers. Here are a half-dozen crowding each other, their wings nervously trembling with excitement. Among them is one with a bit taken out of each wing; the gaps are of the same pattern. It is the work of a bird. The insect was seized while at rest with wings together: in no other way could it be done. Birds are their greatest enemies. One often sees them with tattered and broken wings, where they have escaped as by the skin of their teeth. Any of our insect-eating birds will now and then make a dash for a butterfly, but to actually capture one is not an easy matter. One often hears the expression a "butterfly existence," meaning a life of gay trifling, flitting here and there among sweets all the long summer days in peace and security. It is all a mistake. Nature bestows these blessings in full measure on no living thing. Struggle and warfare, fighting and dodging, creeping upon and being crept upon, are what we find in every department of life. Our pretty yellow and black butterfly does not find nectar in every flower he visits : other hungry insects may have drained it of sweets. Many blossoms are so made that he cannot partake of their treasures. One may see them try this one and that one during a half- 
hour, only to be unrewarded, and all the time obliged to keep a sharp lookout for hungry birds. It takes some food to furnish energy to keep up their flight. They will gladly help themselves from sap that issues from a wounded tree, and some nourishment there must be in the muddy water, and it helps them over a hard time. I have known this species to frequent the drainage of a distillery, and become so drunk they could not fly, and the birds made havoc of them in great numbers, till their wings were scattered like autumn leaves over the treacherous ground - an insect tragedy resulting from the same agency that has so often torn and crushed the wings of human hope and love.

These individuals now flying here and there have all come forth out of great tribulations and hairbreadth escapes. It is but early summer yet, and before the ground freezes nearly all will have been eaten, or fatally wounded. The battered remnant will perish of cold, and not one of them will see the sun of another summer. Let us look a little further into this matter. Each female will lay not less than two hundred green eggs. These will be placed, one here, and another there, on leaves of trees - apple, plum, cherry, birch, willow, etc. In two weeks, if nothing serious has happened to them, they 
will hatch. Now the serious thing that may happen is this : a very small fly with a very large concern for her future brood, thinks she knows a good thing when she sees it, and if she finds these eggs there will be no butterflies ever come from them, but her own kind of flies instead. She is provided with a sharp hollow tube that connects with the eggs in her own body. She thrusts it into the butterfly's egg, and sends through a dozen or more of her own, and then serves others in the same way. Now if this event does not happen, and no other accident befalls them, the butterfly's egg will hatch, and out of it will come a tiny brown caterpillar, and then the battle begins in earnest. Enemies, from ants to birds, are looking for him. The chances to ever reach the butterfly stage are not one to one hundred, but he is bound to make trial for that chance. He begins to gnaw the leaf and spin a bit of web carpet to stretch himself upon when not at work eating. As he feeds, his skin becomes tighter, and in four days it bursts open and he is larger and a little changed in color. In five days more he has become too big for his jacket and moults again. Then he is about one-half inch in length, quite green with the exception of a little marking; this color like the leaf is a great advantage, 
now that he is quite large enough to be seen. If he were red or black on a green leaf the chances of escaping would be very much less. The larger he grows the greater his danger. But all this was understood when two hundred eggs were laid - the number was in proportion to the enemies and risks to be run. In four days more the skin gives out again, it is sloughed off and he is an inch in length, green, with a brown head and dash of yellow in dots, with a very few short hairs. The moulting business is almost complete, and still he is a long way from a butterfly. It has been a dangerous journey thus far, helplessly hanging to a leaf in the presence of enemies, but if he were to take another step out in the open all would be over with him. If he moulted and showed his sprouting wings, yellow against the green leaves, a bird would be blind that did not see him. When he is a butterfly there will be no more eating solid food with jaws, but it will be daintily sipped through a delicate tube. To try to live outside while such a change was being made would end in starvation if death came in no other manner. Old Nature knows the way! So this thing must be done in a sealed up ehamber. No eye shall look in upon the mystery of transformation by which this lowly grub is to 
become a winged beauty caressing the clover and lilacs, and slanting down the sunbeams on gilded vans. Before the next step is taken the eaterpillar makes himself fast by a loop of web to a leaf, or leafstalk, or twig, and becomes by another change a ehrysalis - a hard shell with a blunt end for the head, outlines of eases under which the wings will grow, and all of a dull oldgold color, with the tail end fastened by web to the leaf or twig, looking like an Indian pappoose on its mother's back. It has now to run the risks of hungry birds for many months till the next spring. More than that, there are small flies all fitted with hollow drills, to make holes in this ehrysalis, and through these drills shoot their eggs into what promised to become a butterfly, and under the new arrangement will only furnish food for another insect. Such are Nature's ways, and, begin where we will to investigate her, she presently leads us into worlds of wonders, where the wisest of mortals is a stranger.

One might conclude that the object of Nature was to ereate a beautiful butterfly to enjoy itself playing hicle-and-seek among the flowers, sipping their sweets and bathing in the sunshine. One might think that these crawling caterpillars are only steps to this beautiful and delightful end. 
The hard facts do not agree with such conclusions. There are butterflies that never feed at all, because they have no proper mouth for the purpose ; they mate, and lay eggs, and starve to death in a few days. Moths are mere nightflying butterflies, and there are moths, like the wellknown gypsy moth, of which the female, a beautiful creature, lays her eggs a few hours after coming out of the chrysalis, and lingers near them, and dies in a few days without feeding, although she has the means to do so. The males live on a much longer time.

There is a species of moths to be found in this Province of which the female never has wings, but lays eggs the same, while the male is decked out in pretty buff-brown wings, enjoying life in moth fashion. This has no common name. It is known as Orygia leucostigma.

Again, there are caterpillars that actually lay eggs without mating, and these eggs produce other caterpillars that produce butterflies. This is evideutly a move to keep from being utterly extinguished by their enemies. Then, there are moths that never mate and yet produce eggs that are fertile, but the caterpillars are apt to be mostly all of one sex.

There are a great many small flies that drill holes in the eggs and in the chrysalis of butter- 
flies and moths, and by so doing they keep down these crawling pests, that would otherwise give us much more trouble than they do. In New England, and especially Massachusetts, there is a small moth that was brought from Europe thirty years ago by a French naturalist in order to make some experiments about its ability to spin web useful for making silk. Three or four of these insects escaped in the town of Medford. In ten years they began to make trouble, as their caterpillars fed on almost all kinds of leaves and they gained in numbers. In twenty years they were very destructive in Medford and had extended in small numbers to other localities, and there was a fight kept up by owners of orchards, and gardens, and woodlands; but still the enemy increased. Nine years ago the State Legislature was petitioned to find some means to abate this seourge. Twenty-five thousand dollars was voted to be expended in fighting this enemy. The next year fifty thousand dollars was voted for this war fund, and the battle raged with fire and poisons and tar, but the caterpillars continued to increase.

In 1892 the Legislature voted seventy-five thousand dollars for the annual "Gypsy Moth Fund," as it was called. In 1893 it was infesting thirty cities and towns, and laying waste the 
country, and the Legislature voted one hundred thousand dollars to carry on the war. During 1892 and 1893 the committee in charge of the work asked for much more than they received. In 1894 one hundred thousand was again voted Then it was considered of national importance, and Congress was petitioned to come to the aid from the National Treasury, and forty thousand dollars was voted. In 1895 Massachusetts voted one hundred and fifty thousand dollars for that year, and three hundred men were constantly in the fight with these caterpillars, eggs, and moths. Since that date the sum has increased. and now the Legislature is petitioned for about five hundred thousand dollars to be expended in the expectation that this pest may be got under so it may be kept there for a few thousand a year.

I tell this story to show how easy it is for even a single species of insect to destroy all crops. It is only by the help of birds and other insects that destroy their eggs and caterpillars that man is able to live on this earth. If the gypsy moth had not been opposed wholesale there would not be a living orchard or green bit of woodland in New England to-day, and it would be useless to plant a crop. 


\section{OAK APPLES.}

"IT is impossible to walk across so much as a rood of the natural earth, with mind unagitated and rightly poised, without receiving strength from some stone, flower, leaf or sound, nor without a sense as of dew falling on you out of the sky." - DR. SA MUEL JOHNSON.

\section{A S I jogged along this cool autumn morning $A$ more than once I pulled up my faithful} old horse and got out. He had by long experience become acquainted with my habits, as I had his. He did not approve of my liking to investigate so many things by the wayside. His preference was to go straight on to the end of the journey, and he followed me with his eyes reprovingly till I took my seat again. This morning seemed a favorable time to collect some objects of interest. There were plenty of them, and well worth study and observation. I could have had empty bird's-nests, telling much of the little builders. I could have had toadstools of various species, all of them with curious histories and habits; but coming upon some "oak apples," I filled a pocket with the 
hollow things and went my way, and now we will discuss them.

I recall that when I was a boy it seemed singular to me that such a plump, tight, inviting looking fruit with a nice name was clearly no apple at all, and utterly unfit to eat. When broken open it proved to be nearly all shell. In the centre of it was a spidery looking lump, hard and woody. If some person had come forward and explained the difficulty how gladly would he have been received, but the aptitudes and eager curiosity of children are but little heeded, and if all taste and talent are not either quenched by open rebuke or servile drudgery it is because some finer traits can survive even the most unfriendly treatment.

We will now cut open this apple and take out this spider-like core and carefully open it. Separating it into several pieces we find three or four small grubs, alive and active. The first question is to learn how they got there. There are no holes through which they entered. They were hatched from eggs where they are. Now there are flies that lay their eggs in apple blossoms just where the tiny apples begin, and these hatch, and hence the worms in the apples.

The same takes place in other fruit. Here 
in the oak apple we have in the grubs, the young of a small fly. The female has a hollow drill connected with the eggs in her body. She is a gall-fly, and the proper name of these apples is gall. When the season comes around the gall-fly finds an oak-tree, and in a tiny growing leaf or twig she drills a hole and shoots into it her eggs, three or four in number, and then repeats the operation. Now we may use a needle and prick a bud or leaf, and do what we will in that way there is only a slight scar left; but the work of that drill, finer than a cambric needle, has changed the mode of growth - apparently poisoned the delicate cell-structure. Quickly following the wound the swelling begins, and the result of it is this globular shell, with kernel at the centre of very rich food for grubs, much more nutritious than the leaves of the oak, and there is nothing for them to do but eat and grow fat. This is followed up with occasional moulting of the old skin, till another stage is reached, when they become pups, do themselves up in tiny cases, and wait for wings and other organs like their parents. When this is done they gnaw out of their prison, and join their kind in the outside world. The fly is about one-quarter of an inch in length. It is not difficult to get them by plucking the green apples 
and keeping them in a box till they come out. Now there are very many species of gall-flies, but each kind has its own tree, or shrub, or plant in which the eggs are placed. Here, then, we have in this oak gall a most curious and interesting object. It turns out to be an inhabited house provided with food for tiny helpless creatures, that, so far as we can see, serve no useful purpose, and have no great enjoyment of existence. But the fact is that here is a welldevised plan in their interest. The mother, a small four-winged fly, is provided with an eggdepositor and drill combined, most delicate and ingeniously contrived and constructed for its purpose. This tool would be of no value without intelligence to use it, and therefore we have in this mere mote, the faculty to distinguish an oak-tree from others, and the skill to get the drill in place and make a proper use of it when there. Shall we go further and say that she knows the eggs she never saw will produce grubs that must have food and shelter? If she does know that, then is she endowed with some higher faculty than we are; if she does not, then she is a machine, acting because she must and not because she wills. If we flinch about accepting that view, we are at once driven to the same thing with the oak-tree that becomes 
a party to this transaction, and helps to carry out the plan; and we cannot well hold that the tree exercises any will in the matter, but it must do the proper thing when operated on, or the drill is in vain. This tool implies the helpful co-operation of the tree; with that understanding it was constructed, and the oak lives strictly up to the terms, and becomes fostermother to the brood of an insect, that wounds and poisons the wound to start the apple or gall. This is the golden rule in practice where one would least expect to find it. Say the Hindoo scriptures:

"Be like the sandal-tree that perfumes the ax that cuts it; but the oak, with injured cells, pierced by this Cynips confluens, proceeds at onee to build a neat, safe house, and stores around the eggs a concentrated food, and introduces a bitter element into the apple shell, to make it distasteful to birds and squirrels, and grows horns and legs in the eradle of the grubs in order that no prying jay or woodpecker shall try to swallow it."

Here we are dealing with small objects as we are wont to measure them, but they are deeply involved with great questions. Saturn and his rings and moons in all their stately grandeur are not invested with the reverent interest 
awakened by this tiny gall, that we crush in our fingers, or pass unheeded in our walks abroad.

We are not yet at the end of our story. If we collect a dozen or more of these oak apples, and keep them in boxes till the flies appearand that may be over winter in some instances - we will be quite sure to find that there are at least two species, looking very much alike to untrained eyes. One of these is a gall-fly, the other is a guest-fly - he is an uninvited guest of the owners of the gall. He is the offspring of a mother that could drill a hole and lay her eggs in a gall after it was started, but had no power to begin one on her own account. She probably lacks the poison organ for such an operation. Here, then, is a creature equipped with a fine arrangement to take advantage of the cooperation of the oak-tree and gall-fly, and make them provide for her brood. 'There seems to be a moral disorder in nature : there is no sense of fair play; pirates and plunderers and parasites abound everywhere. These guest-flies are a numerous race, living always as young ones on the ready-made galls, or often grubs of the gallmakers.

Not without some service to mankind are these oak galls. They lave long been used in 
the preparation of the best inks, and still are an article of commerce. They are produced in Asia Minor in a species of oak. Shakespeare says :

"Thither write, my queen, And with mine eyes I'll drink the words you send, Though ink be made of gall." 


\section{HARES.}

"THE origin, history, and structure of animals, their habits, senses, and intelligence, offer an endless field of interest and wonder."LUBBOCK.

AL the year through rabbits, or properly A hares, are common objects on the Molega Road. In the spring, when the grass starts up by the wayside, there is a standing invitation to these little creatures to come and partake of this new bounty of nature. No doubt it is a very delicious change from the steady diet of twigs and bark. They have become very tame, and do not run away at the approach of teams, but merely take a few leaps to one side. I sometimes see them in playful mood, bounding here and there about each other like lambs. Mornings and evenings are the best times to find them, for they do not often venture from their "forms" or hiding places later in the day. The hare has had his part in superstitious whims of people. It is a wide-spread belief in many portions of Europe that witches transform themselves into hares, and it is generally considered a bad sign 
to meet one. "Melancholy as a hare" is the way Shakespeare has it, and he is always in touch with the common people and all their sayings. After the little fellow was dead, then there was a better opinion of him, as often turns out with mortal man. The great Francis Bacon tells us with due solemnity that "The brains of hares are very serviceable for strengthening the memory and brightening up the faculties," when made into a palatable dish. If there is any truth in his assertion, he should have strongly recommended a liberal diet of that sort of thing to most people. Another old English writer gravely tells us that "The knee-bone of a hare taken out when the animal is alive, and worne about the necke, is excellente against convulsive fits." There was scant consideration for the poor brute in that remedy. To carry in the pocket the right foot of a hare was once considered a fine remedy for rheumatism. It might answer such a purpose. Horse-chestnuts, or a potato carried in a pocket for rheumatism, have worked like charms, and that is the virtue of the cure, their faith has made them whole. One can see now, in 1899, the fore feet of rabbits, mounted in silver, and offered for sale in shop windows of Boston as charms much in use by smart people. 
But we will return to Molega Road and its attractions. In the winter twilight one may see them quietly browsing, or bounding here and there as noiseless as ghosts. They have a habit of taking a course through the bushes where there is the least obstruction of limbs, and thus beat out paths through the moss, and in the winter through the snow. They prefer to run in these paths, and turn out here and there to feed. Boys are aware of their habits, and easily snare them by placing a small pole across the path and tying a wire snare to it, and sticking some brush cunningly on each side of the snare to hold it steady, and bar up all other ways but the one through the snare. Now Bunny could jump over the pole with the greatest ease, but he will not; he stops, lays his ears well back, and carefully puts his head into the snare as if he were bent on committing suicide. In a moment the fatal noose is tightened about his neck, he jumps here and there in the most frantic fashion, and ends by strangling. The owner of the snare finds him in the morning, a few feet from the path, all "drawn up" and frozen, even to his eyes. Sometimes the snare is tied to a bent sapling, and the rabbit in his struggle sets it free, only to find himself dangling in mid-air. Either his meat, or his fur, or both, is the 
temptation to take his life, and the average boy has no "bowels of compassion" for wild animals. The boys seem to have all had the apostolic vision, and heard the command, "Rise, Peter, kill and eat."

Hares are not very intelligent creatures anywhere, and our species is no exception to the rule. The fact is that his manner of life is against him. For hundreds of thousands of years he has not done anything to add a brain cell to his slender outfit. The fossil remains of this family are found in ancient rocks of the Tertiary Time, in Dacotah and elsewhere. He has changed somewhat in structure since then, but his teeth indicate that his feeding habits have not changed. In the many divisions and subdivisions of the quadruped mammalian life, that come about largely through struggle for existence, the hare family was evolved, or slowly formed, with adaptations to eat and thrive upon food that existed in plenty, and for which it would not have to dispute with other animals. Tender twigs and leaves, and wild grasses and barks of trees, all of them the products of waste places, were things he desired for food. To secure them no planning was needed, no demand was made for intelligence. A few leaps here and there, and he could fill himself like an ox 
with this coarse food, and retire into his hiding place a whole day while it digested. Under such circumstances no animal advances in brain capacity. Such gifts of the brain are won out of the stress, and struggle, and makeshifts that our most intelligent creatures have experienced. The species of animal that does not feel the spur of necessity urging the use of brain power will either remain comparatively stupid, or degenerate into deformed parasites. It is a stern law of nature that the possessor of one talent must put it out at some kind of profit, or even that shall be taken away. Says Josh Billings, "Them as has gets." Rabbits find life too easy. They fulfil the promise of the Psalmist, "The meek shall eat and be satisfied." If it is just as well to be stupid and filled to the throat with bark and browse as it is to be smart and clever, then "Br. Rabbit" needs no sympathy. The old Romans had a saying, that " $\mathrm{He}$ who knows nothing spends the happiest life." That may be true, but what is the quality of the happiness? Is it not more desirable to be Newton, demonstrating the problems of planetary movements, than it is to be a toad under a leaf absorbed in catching bugs and beetles? One truth can be clearly made out in the study of organic life, and it is this: Through millions 
of years living forms have become more complex and more intelligent, until man energes from the process, and asks, "From whence have I come and whither am I going?" One may fairly hold, in view of this fact, that to become more intelligent is advancement for any animal; to become less intelligent is to go backward and fall out of line, and lose rank in the march of life. Compared with a weasel, or a mink, or a fox, or a crow, our rabbit is an idiot. All of these creatures live on concentrated food, and they are busy in search of it, with their senses alert. This hare family are great for multiplying and replenishing the earth. Two and three litters in a season, and several in a litter, is the regular practice. If it were not for their enemies they would soon drive us from our farms. If these animals were creatures of more brains there would be fewer young. The power of reproduction is gauged and proportioned to the dangers that are sure to make an end of many of them before arriving at maturity. A codfish produces a half-million eggs and only two escape to replace the parents. The number of eggs indicates the perils that beset them. English rabbits, not hares, were taken out to Australia where nature had not produced any. They were innocent pets, but they soon spread abroad, 
and began to possess the land as if the promise that "the meek shall inherit the earth" was intended only for themselves. They grew into vast armies, eating every green thing that seemed good for them. In spite of guns, and dogs, and fences by the thousands of miles, they could not be kept within bounds. Now they are killed and dressed wholesale and returned to England for food purposes.

Our species is not a rabbit, but a hare. There are no rabbits in America, but tame ones brought here for pets. They belong to the same family or group, called Leporidoe, but there are marked differences in structure. Rabbits have shorter ears and shorter hinder legs than hares. Rabbits bring forth their young naked in underground burrows, while hares give birth to fur-covered young in open "forms" or partially exposed coverts. As a family the hares are widely distributed, even extending far up into the treeless polar regions, where they manage to subsist on the dwarf Arctic vegetation. There are about twenty-five species in all the world.

I notice that our "rabbits," as we will call them, are evidently on the lookout for enemies, that may at any time attack them. Owls, hawks, wild-cats, foxes, and weasels are all dis- 
posed to kill and eat them. Nature takes many plans to preserve her various species as long as possible. In the case of the rabbit Nature decided that he shall not fight. She made a noncombatant of him, and " his table is always prepared in the presence of his enemies," and this fact is never forgotten by him. He depends upon his eyes and ears to warn him of danger, and then he depends on his hinder legs to take him away from it. It is not often he is caught in a race for life, but he is still-hunted and pounced upon suddenly. Nature has provided another protection in their changing color with the seasons. Doubtless brown is the true color, and white is a seasonal accommodation answering protective purposes. Where there is no snow to speak of they do not become white. In fact our rabbits are only white on the tips of the hairs. I have seen one kept in confinement turn white on all the hinder parts in one night. In the grouse family the ptarmigans change color in the same way. In the Arctic regions, where they live, their greatest enemies are the foxes, but they, too, become white in winter from bluish in summer, and this becomes a very favorable feature, enabling them to creep unperceived on their prey. Arctic wolves and bears and owls are also white. Ravens are com. 
mon in the same regions, and I hardly need to say how black they are. For them to change would serve no useful purpose, for they very largely live on dead carcasses cast up by the waves, or on young birds in their nests, or their eggs. The polar bear remains white in all seasons, and that color may well be the work of natural selection, but the change of color is a subject that needs more light thrown on it by careful study.

It would seem to be the most in line with observations that the change of color is due to the effect of cold on the fur, by which it reflects all the light instead of a portion of it. That the change is beneficial to the hares is very certain, but that it was brought about for their benefit is not at all clear. It would be a good thing for our partridges, but they have got along without it, although their cousins, the ptarmigans of Newfoundland and Quebec, have the advantage of this seasonal change of color. It may be asked, of what benefit is it to inquire about such matters? Why not say, God willed it that hares should turn white in winter and brown in summer? If a very ingenious man made a wonderful piece of machinery and showed it to me, and I merely remarked that I knew he was clever enough to make such a 
thing, and never looked into it further, it would be a very stupid, discourteous treatment of the inventor. We often treat the Maker of all things no better. When the Creator produces, as he always does, vast numbers more than can live, then we may well inquire by what means some survive, and through what causes others die before reaching adult life. We shall find that the fittest survive, those that have some advantage of teeth, or strength, or swiftness, or weapons, or ability to get food, or keep out of sight, etc. The smallest advantage will be of great service, and may win the race of life, when competition is so close. When one thousand men start together for a foot-race, it will be decided by perhaps less than a quarter of an inch; had there been but ten, the victor would probably have gained by many feet. 


\section{WEASELS.}

"SAUCY and as quarrelsome as a weasel." - SHAKE SPEARE.

$W^{\text {Easels do not appear to be common }}$ with us, or in fact anywhere. This winter morning I saw one dodging in and out a pile of snow-covered brush. All his upper parts were nearly as white as the snow, his thighs and under portions a sulphury-yellowish, the tip of his tail jet-black. This is the ermine weasel, Putorius erminea. We are credited by writers with another species, Putorius vulgaris, about the same size, with a shorter tail, no sulphuryellowish, no black on the tip of the tail. If we have this latter species it must be much rarer than the former, which I will proceed to discuss. This white dress is the weasel's winter coat, as most people know, but it is not generally observed that his under parts are always white or yellowish-white. In the warm season he is a mahogany brown on the back and sides. This change of color is worth consideration. There can be no question but the change is a decided 
advantage to the weasel. He lives by hunting, and to be as white as the snow prevents his intended victims from readily seeing him. The under portion of his body is not exposed, and summer and winter remains unchanged. Where there is little or no snow these animals retain the brown and white all the year. There is some question whether the white is a new hair in the fall, and the brown a new coat in the spring. I think the truth is that the old coat turns rapidly white with cold weather, but this is replaced by a new brown one in the spring. If we got at the roots of this matter of change, it seems to me it would be found that the whitening is due to the cold; that it serves a good purpose for the animal — is rather a lucky hit for him than a providential purpose. Brutes, as well as other people, find luck in their favor sometimes. If it is providential design, why not bestow it upon our red squirrels and partridges, and all winter birds and beasts? It would be a fine thing for them all. If it were not for this advantage in color, the weasel would not be found among the snow. It is hard enough, as matters stand for him, to make a living, but without this advantage the unequal fight would be useless. This animal is able to stay just because he is helped out by his natural 
variation of color. In all living creatures one sees adaptations of many kinds to enable them to secure their prey or hide from their enemies, but nowhere is man and a snare, or a trap, or a shotgun taken into account with them. This shows that we are the latest arrivals. Before our coming it was all scratching and biting and running and hiding; but the human animal twisted a withe handle around a stone and made a club, tied string to a limb and made a bow, dug a pit and covered it for a trap; in short, he turned mind and wit against the shaggy horde and mastered them. I am led to this remark by the fact that this beautiful mimicry of the snow in the white of the weasels, that proved so advantageous to them, has been the cause of their greatest slaughter; for men took a fancy to the dainty ermine fur, and countless numbers have been killed to satisfy the demand.

So Nature provided the Arctic seals with beautiful close, soft fur, but human animals were not anticipated, who would kill them to the last pup and pelt for this gift of Mother Nature to her four-footed children. Birds of such delightful plumage that millions of years have been covered while natural forces were at work perfecting them; but man comes on the scene, exclaims, "This is all mine!" and, the primitive 
savage that he is, kills the most beautiful birds to make a head-dress for himself and a girdle for his swarthy mate; and although many, many thousands of years have passed away since then, still the finest feathered gems are sacrificed to the lingering love of ormament and display.

But we will not forget my weasel! I am bound to confess, despite his pure, innocent matching of the "beautiful snow," that he is far from attractive. There is something serpentlike in his aspect and general make-up. His flat, triangular, rattlesnake head, almost deformed by great jaw muscles, is set on his long neck with a vicious cant like a hoe on a haudle; his bearly black eyes seem so eager and wakeful that one may well believe that it would be hard "to catch a weasel asleep." There is nothing frolicsome and prankish in his appearance. Keen, inquisitive, restless, bloodthirsty, cruel, courageous, these describe his leading characteristics. He is a creature of solitary habits, prefers his own eompany to any other, and shares neither his luck nor his misery with another. No other animal of its size is possessed of such audacious pluck. They will seize a rabbit, or partridge, or hen, and overmaster them in many instances. When it comes to eating they pre- 
fer the brains and next the blood. When neither of these dainties are to be had they will take the next best. Young birds in their nests, mice and rats and insects, all are appreciated. Squirrels fall victims to their rapacity, especially the striped squirrel, for he dives into a hole, and there his pursuer will fiuish him. He can also climb a tree, and swim a stream. When he is in especial good luck, and kills several mice and birds within a small space, he drags them together, perhaps to better guard them, perhaps to make a better showing and please his pride. When his larder is full, and he has a bit to spare, he buries it out of sight - a very common and widespread instinct. Sometimes a mousing hawk or owl seizes a weasel in his claws, and flies away to make a meal of him; unless he has been careful about securing his head and neck, he will get even by eating into the vitals of his captor and bring him to the ground in a death struggle, while he gets off with a few scratches and lives to feast on the brains of his big enemy. If revenge is sweet, then the little fellow has his morsel well sauced with it.

Among the delicacies of weasels, one must not forget to mention eggs of birds and fowl. Shakespeare, who was once a country boy, and knew all the beasts and birds and plants and 
creeping things, makes Jacques say in "As You Like It":

"I can suck melancholy out of a song as a weasel sucks eggs."

And again in "Henry V":

"For once the eagle England being in prey, To her unguarded nest the weasel Scot

Comes sneaking, and so sucks her princely eggs."

It is a rare find to come across a nest-full of young weasels; the mother seeks out a place in a hollow log, or beneath stones or trees, and there gives birth to four or five young, and this occurs early in the season. They have been found when the mother was white in winter dress. She is a bold defender of her young to the utmost. In some localities more than one litter is born in a season. Such rapid multiplication of a creature like this ought to make them very abundant, but they are not. It is a very interesting question, what keeps them in check? So many young in a litter indicates a special danger, but I hardly know an enemy but mankind, and but few are destroyed with us by traps or guns. They are strong, hardy, acute animals favored by changing colors, and food enough and to spare, and yet not one in 
four of their young comes to maturity. Evidently here is opportunity to learn something of interest.

In North America there are several species of weasel, and a larger relative, the American blackfooted stoat, twenty inches in length. This animal is found in Kansas and other Western States. It is rare, in fact very rare, and seems to live mostly on the little rodents known as prairie dogs. These live in underground burrows, congregating into villages, where grass can be found for food. The stoat attacks them in their dens, although they are nearly as large, with teeth like rats, and disposed to use them when cornered. Great numbers of weasel skins were once sent to Europe from the Hudson Bay region with other furs, but now they are not in much demand. 


\section{SPIDERS.}

“THE spider taketh hold with her hands, and is in king's palaces. Proverbs xxx, 28.

F all the little folks about us but few are more common than spiders; none are better worth study, and yet they are neither liked nor admired, and but few give them careful attention. They are not properly insects but more nearly related to scorpions and crabs. It is a very large group, embracing many genera and species. With rare exceptions, and they do not exist with us, spiders are entirely harmless. They are not inclined to bite; occasionally they do, but I have never heard of such a wound causing much pain but in one instance. These animals are not only harmless but they are very good friends of mankind. They live altogether on insects except when the females turn cannibals and devour their feebler mates. Unless one carefully took into consideration the great numbers of our spiders, he would scarcely do justice to their good services in our behalf. 
She not only taketh hold with her hands in king's palaces but she festoons the dingy attic and cellars with silken nets. She covers the fields, and pastures, and shrubs, and orchards, and fences, with dainty traps, which are tended and repaired and watched with hungry eyes for victims.

I have been induced to write this chapter on account of the interesting features that come within its scope, but perhaps it would not have been written but for the fact that a recent early morning ride to the mine gave me a capital opportunity to see spider's' webs everywhere decked in glittering gems of dew, that served to make them not only visible but beautiful in the level sunbeans. They were stretched across the road in sagging curves, threaded closely with beads that unbraided the white light of the sunbeam, and revealed its hidden rainbow of colors. From naked branches and fragrant fir limbs they hung in dainty wheels, woven in spokes and spirals, and braced with skill and judgment. They carpeted the unsightly brush-piles in gleaming gossamer. Under the magic of dew and sunshine the works of these marvellous spinners and weavers stood revealed. Many species had taken part in the performance. Each one had its own way of constructing a trap. All this decking the 
roadside was not done with an eye to beauty; there was no thought about the gentle dew adorning them with jewels; no consideration that the sunbeams would be wrecked in their pendant pearls, and a human eye would be there to enjoy the spectacle. Quite otherwise: every net had been made for the special purpose of entangling some living thing. As a rule, only the female spiders can make webs. The males are smaller, slimmer, and prowl around the webs of species smaller than their own kind, and rob them. When pressed by hunger they will venture a combat with a female of their species, for the sake of a meal on a captured fly. Not very long ago I witnessed an encounter of that kind. The female, one of the wheel-making kind, a strong, active thing, that would more than cover a copper cent, had made a fine trap between two bits of a timber of a bridge. It was about a foot across. She sat in the centre, with each foot grasping a spoke and thus able to quickly feel any disturbance, and ready to run toward the point where a fly would be caught. The twilight was over all, and spider-life was becoming very active. A large male spider that had been in hiding near the fly-trap of his relative - one of the same species - ran quickly out on the edge of the web, seized a thread of it and 
jerked it rapidly, to learn if the owner was at the centre. Neither of them could trust their sight for that distance. The vigilant proprietress seemed to know at once that this was no struggling fly or moth. There was an unmistakable defiant twang of the web that told another story. Her rights were evidently being invaded. She would have twanged the spokes herself had it been a victim, to make sure of the impression, but now she ran straight to the intruder. He hesitated, but concluded to fight. They were bent on biting. Each of them sparred for a chance to seize the other by a leg, and as there were sixteen between the two, it was rather spry work to take care of them. After a fierce round of a half-minute the female drove him to the outside ropes of the web. At that point each one lost a leg, but like

"Worthington, of doleful dumps,

Who when his legs were smitten off,

He fought upon his stumps,"

they did not appear to notice their loss. They would withdraw from a grapple for a few seconds and then renew the combat. In one of these mind-collecting moments the female made a dash for the centre of the web and gathered herself sulkingly into a vigilant attitude. The male followed a bit into the disputed territory, 
and contented himself with "daring her out" by strumming on the cords again. She was uneasy and angry, but as he ventured nearer there was nothing to do but fight or retreat, so she fairly sprang upon him. But he was not asleep; they clinched and kicked, and bit, till they lost their grip on the lines and fell out of sight, locked in as venomous and spiteful an embrace as one could witness. 'Two tigers could not have outdone them in every appearance of anger. The female generally wins. She will kill and eat the male who would have been the father of her brood.

Let us go back on our track a little. When a true bug or beetle or fly is hatched, a worm is the first result - not a true worm but a grub, and it matures by undergoing many changes. A spider is born complete. As he increases in size he sheds or moults his skin or shell like lobsters. They have six pairs of limbs: four pairs are used for legs; a pair of palpi, or feelers, used also for other purposes; a hinder pair of legs are used to guide the thread. They are furnished with three claws and a brush of fine hair; the other legs are clawed in the same way. On the under side, a little behind the first pair of legs, are two nostrils, concealed by covers. At the end of the body, 
and somewhat beneath, are the spinnerets; there are three pairs. The webbing or silk issues from the body through these holes and becomes joined in one thread afterwards. It is often asked, how spiders string their single lines from tree-top to tree-top, across roads or from building to building? Having crawled up to a desirable elevation, they start the thread either by a muscular effort or by sticking the end to a limb or board, and then "pay" it out by using the hinder feet to pull it out of the body. The slight wind will do the rest, drifting it upon some holding-ground where it ties itself. Small spiders in great numbers are carried through the air at the end of long weblines.

In South America a web is made by a large spider, in which small birds are caught and held fast; the owner greedily feeds on them. To tell of all their curious and often wonderful nests and traps would be a long story, but an interesting and instructive one. As a rule, spiders trail their webs along, to be ready for any emergency. With a sudden breath you may blow one of them from his position to give him a fall, but it will be found that he is dangling at the end of a thread. On the water they are generally very much at home, and our 
black water spider does not make a web, but lurks about the shores and springs on its victim.

Here I must take leave of these most interesting little animals. Their habits, instincts, structures and dispositions are all marked with peculiar distinctness, and a careful study of them is no idle amusement but a pleasant and praiseworthy task. 


\section{A GOLD MINE.}

"SURELY there is a vein for silver and a place for gold where they fine it." - Јов xxviii.

\section{A FTER loitering so long on a road that A leads to a gold mining district it might} seem in order to devote a chapter to this natural feature of the country. Falling in with that view I will proceed to put down what strikes me to be the most interesting features. If $I$ do not succeed in making a readable chapter for those who like this kind of literature, it will not be for lack of experience or want of interest on my part. I do not know of any branch of human industry where there are such misconceptions, delusions and utter ignorance as there is in the matter of gold mining, and how gold exists in its natural conditions and locations. In the first place, gold is not a rare metal. Chemically combined with the element chlorine it exists in all ocean water to the value of about three cents to a ton of water. Gold in minute quantities to the cubic 
foot is often found distributed over wide ranges of country. But to find gold, brought together by natural operations in sufficient quantities to mine it with profit, is the difficult point. To find gold in rocks or gravel is not a matter requiring much effort. So far as we know, all the gold that man has obtained in Nova Scotia has either been mined out of a quartz vein or washed out of gravel containing gold that has been broken out of veins and washed into the surface by natural agencies; and apparently this is true over all the earth.

Let us first get a clear idea of a mineral vein or lead. If the rocks of all this region were completely stripped of the covering of gravel, sand, mud and clay, and laid clean and naked to view, we would see long broken ledges in upturned positions, rumning easterly and westerly sometimes the layers would be standing on edge, quite perpendicular, and in that case they would be found to slant or "dip" or incline, gradually increasing the slant with the distance on both sides of the perpendicular and in opposite directions. If you will set a book on its edge, and then lean against it, on each side, other books, bracing against the central one and supporting it in place, you will then have the position of the rocks, only the books 



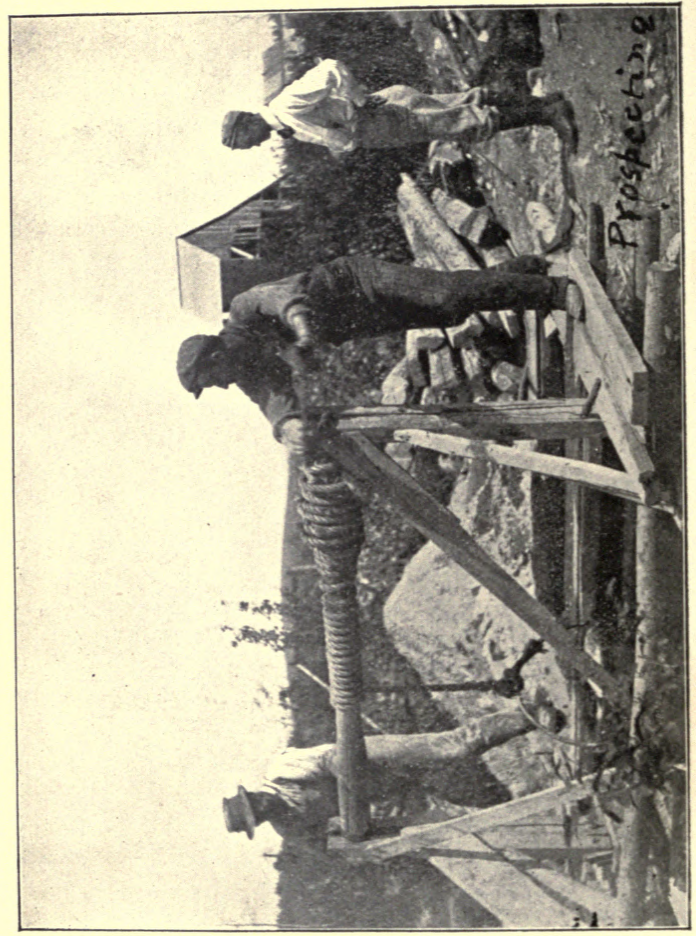


must slant more and more till they are flat, and then begin to be piled up to make another book ledge. At the point where the rocks or strata are perpendicular it is termed an anteclinal; at the point where they have flattened out it is termed a synclinal. Now from one of these anteclinals to another the distance is generally several miles. The ledges or strata are all of two varieties - quartzite and slate; they rest against each other in alternating layers, perhaps of a few feet, or many feet, or a few inches in width. Both of these kinds of rocks are of shore origin; they are sediments and sands ground up on a seashore many million years ago; there can be no proper question as to this statement. Now supposing that all the region is bare, we would see white lines running along between the layers of rocks ; examination would show that they were veins of hard rock, varying in width from a mere line to five feet, and running easterly and westerly with the ledges in which they are enclosed. If you will put leaves of paper and pasteboard between the books I have imagined to be piled up, then these will show the positions of the veins in the rocks. Then you will see that some veins will be perpendicular and others more or less slanting; these are called "regular" veins, or interstrati- 
fied or interbedded veins. If all were clear as we suppose, other veins in plenty would be seen running in various directions and entering the rocks at differing angles. These are known as "angulars" or "crossleads." In both kinds of leads or veins they are formed of white quartz or silica.

In conditions like we have here imagined, where nothing would hide the solid surface of rocks, there would be no great difficulty for the "first comers" to locate a gold mine that would be a fortune in itself. It would only be necessary to examine these white lines of outcropping quartz veins, where gold would be found in some of them, and then select the richest veins. As matters now stand, the once bare rocks and veins are covered throughout the district, with few exceptions, with an average depth of seven or eight feet of gravel, sand and clay. In places this superficial deposit is fifty feet deep. Of course all this upper material is made up of other rocks broken into different degrees of fineness. The underlying "bed rock" or "country rock" belongs to the Silurian group, and therefore to be reckoned among the earliest of water-made or sedimentary formations; but this overlying material, in which all the vegetable life is rooted, is com- 
paratively fresh and new. It is the scattered débris of the great Ice Age, that closed somewhere within one hundred thousand years, reasoning from many data. When that reign of cold prevailed a body of snow, compressed into ice several thousand feet in thickness, covered all the northern portion of North America, and this locality was included. This ice sheet or glacier moved very slowly - a few inches in a day - in a southeasterly direction to the ocean. It was continually fed by snows. In this movement over the naked rocks it carried along fragments of them, frozen in its embrace, and broke off and pushed forward the more exposed projecting veins and ledges. Although no historian of that time wrote this down in a book for us to consult, still Nature herself made a record, readily interpreted and destined to outlast mankind and all his works. The proof is very simple. Let me illustrate: If any one of us had ever seen and carefully observed a bear and his tracks, and afterwards went into another country and saw bear tracks about the woods, he would know the animal had been where he made and left the impressions of his feet. Now there are immense glaciers in Greenland, Alaska and other Polar regions. Of smaller dimensions they are found 
in the Swiss Alps and other mountains. We know his tracks; we can see what he does; and we find the same tracks abundant here on these "Molega Barrens" and all over northern North America.

I would not tell this story about the glacier only that it explains the prospector's mode of operation. In looking for a gold-bearing vein we seek for fragments of quartz on the surface, among the bushes and bracken, and when found they are broken and examined. These pieces of quartz are known as "float" or "drift," and when a promising bit is found the prospector looks northward for more; if he finds other portions of the vein he continues northward until no more are to be found on top of ground; then he begins to dig a trench, still going northward, and, if he succeeds, the vein will be found anywhere from twenty-five to several hundred feet from where the last "float" was obtained on the surface. The reason why the prospector goes northward is because experience has taught him that the fragments of the vein are always south of it. Here science steps in and explains that the glacier was the cause that broke the vein and carried its fragment in its course, and was aided by the rushing floods that moved seaward too, when the Glacial Period 
slowly came to a close, after existing several thousand years. These quartz veins are the meeting-places of the metals all over the world. In them are huddled minerals of almost all known varieties. The metals seem to have their loves or affinities. Never yet was gold found without a trace or more of silver intermingled. Like Ruth with Naomi, there is a tacit declaration that "Whither thou goest I will go, and where thou lodgest I will lodge." Gold, as found in nature, anywhere out of the ocean, is always uncombined with any other element. With silver it is simply alloyed. In these veins at Molega it is associated with base metals, that exist as sulphides. We have chemically combined these: sulphur and iron, or iron pyrites, sulphur and lead, or galena, sulphur and zinc, or blende or "black jack" of the miners; sulphur, iron and copper, or copper pyrites, sulphur, iron and arsenic, or mispicked or "white iron" of the miners. These minerals occuras crystals, distributed in varying quantities through the vein-matter or quartz. The visible gold is to be found usually, either actually in contact with these minerals or very near them. Always there is fine invisible gold caught in the crystals of these base metals. The quantity varies from twenty dollars to two hundred dollars or more 
a ton, over all the Province of Nova Scotia. Here on these Molega ores it is about twenty dollars, and since it is too fine to save in a stamp-mill it is lost, and can only be saved by a chemical process. This fine gold was entrapped in these base-metal crystals when they were formed from solutions that contained the dissolved silica and all its associates in the vein.

It will now be in order to say something about the origin of these quartz veins, that prove so useful to mankind that without them we would not be able to have gold and silver, and copper and tin, and antimony and zinc, and many other metals. Iron ore also occurs very largely in veins. The metals might have existed in the same quantities, and yet be either dissolved in water or scattered in minute quantities through vast strata of rocks. In just those conditions they once existed, and the ocean is the great storehouse of precious metals held in solution, and all the veins in the world contain but a very small percentage of what is distributed through the rocky crust. I know of no other natural feature that seems so clearly to indicate a preparation for the human race as these storehouses of metals these hoards of needed material - brought together by the subtle action of chemical laws working with physical conditions of the crust 
of the earth. Without iron and steel mankind does not advance above barbarism. To conquer the material world he must have tools and machinery. Without metals mankind could neither make a conquest of material nature nor extricate himself from the lower brute stratum of life, and without the metals brought together in veins it would be impossible to obtain them. Thus, "On sinall hinges turn great doors." All veins mark the places of rents or cracks in the rocks; no matter whether they are great fissure veins many miles in length, and from ten to two or three hundred feet in width in places, or whether they are only a few feet in length and thinner than a knife blade, the origin is the same ; they are healed rents.

For the most part, over all the earth this mending or healing the wound is done with silica or quartz. This is a very common mineral, entering largely into the composition of almost all kinds of rocks. It is one of nature's main materials used in the construction of this earth. When analyzed by a chemist it is found to be made of two elements, namely, oxygen, on which we depend for the breath of life, and silicon, a metal never found outside of the clutches of this terrible oxygen. They are interlocked in an embrace that was formed when the earth was 
a fluid mass; it will not be broken till the elements shall "melt with fervent heat" and our planet reduced to vapors again. Here in the quartz of the world is oxygen sufficient for another atmosphere; but it is " retired from circulation"; its terrors are masked and bound by silicon, its affinity. Free in the air, where it is intermingled with nitrogen, its activities produce the heat in all animals, the flames of all fires, the rust on all metals. It gives color to the blood that blushes on a maiden's cheek, kindles the first breath of all infancy, and feeds the torch of life to the last throb of vitality. It dissolves into elemental stuff the lifeless bodies of all creatures. It builds and burns with ceaseless activity and awful energy, tearing down mountains, roaring in the volcano's throat, and yet tending the vital flame in the tiniest insects and pulsing through microscopic structures where all life would cease without its tireless ministrations.

Such, then, is this beneficent but awful agency meekly slumbering in this flint, or quartz, or silica that makes up the material of our veins. Mingled through it are the other minerals, and gold among them. Nothing can be clearer than this to an observer. This quartz was not melted when the metals were introduced 
into it; in that case they would be arranged in layers according to their specific gravity or weight, but they are not. Then, again, the most delicate crystals and threads of gold are mingled and interlaced in such ways that a melted mass forced up into the rents would not permit to form. The explanation is that the quartz was introduced into all veins either from below through the agencies of hot water and steam, in which it and all its metals were dissolved, or it oozed from the walls out of the surrounding rocks, through which there is al ways a circulation of water. There are abundant reasons for this explanation, but here there is no space for stating them. At the Steamboat Hot Springs of Nevada this making a quartz vein with metallic contents is going on to-day, and open to all observers, and it is accomplished as I have indicated.

Now for a little further notice about gold. It is mined with drills, picks and shovels, and dynamite in the hands of strong, hardy men. They do not " dig" gold only in gravel deposits. With us the quartz is blasted out, and hauled to a stamping-mill or crusher, where it is pounded into sand by stamps weighing about nine hundred pounds each. The gold is thus cleared from the quartz, melted into bars, and sold in New York to the United States Government. 


\section{LUNCH BY THE BROOKSIDE.}

" AND this our life, exempt from public haunts, Finds tongues in trees, books in the running brooks, Sermons in stones, and good in everything." - SHA KESPEARE.

$A^{T}$ a distance of more than a mile in the A Molega Road is the crossing of a small brook on a pole bridge. At this point the stream, about a rod in width, is gently rumning over a gravel bed, and half hiding in the bushes as it makes its way to the river, nearly a mile away. For a small part of that distance it tumbles along the margin of a neglected field, and then dives into the primeval forests of birch, oaks, hemlocks and firs, carpeted with mosses and hung with lichens.

Reaching the edge of the wood before it does the river it leaves the shadows, and with many a turn and twist, through a stretch of meadow, where the hardhacks and the polypods fringe its banks, and the herons hide, and bittens boom, it joins at last " the brimming river." Slyly gliding behind a little hemlock islet it there mingles its waters with the greater stream. 
But let us return to the little bridge. From the northward comes the brook, winding here and there through meadow and swamp, from its source miles away among the hills and barrens. For the most part of the distance it has loitered through meadows, where it becomes deep and smooth - a beautiful mirror reflecting the upper world in softened shades, where the sky is a tenderer blue, and shrubs and grass and trees are therein pictured with a softening touch of beauty. Hither come the herons to dress their plumes, the swallows to run down their prey, and the dragon-flies all day long court this "amorous looking-glass" in many a wayward dash and turn.

But I must not loiter also. Here, then, betwixt the road and a pole dam, we will rest and refresh ourselves with the water at our feet. There are so many native inhabitants of this spot that one will needs be blind not to heed them. Without stirring ten rods away one might find enough of life to employ him for years in observing it and writing down what he learned. At a venture, within a circle of ten rods in diameter grow fifty different species of plants or vegetable life ; of animal life, including birds and beasts and insects of all kinds, there are still more. One may sit on this tiny rustic bridge, and luxuriously hang his legs over the end of it, till his feet almost 
touch the water, where the long-legged skippers are hurrying in hasty skating-like strides hither and thither. These are a species of bugs. There is a rather large family of them. The older name of our species is Gerris remiges. If one will throw crumbs of bread to them they will eagerly seize bits of it and scurry away as fast as possible. Some of them are provided with wings, but I have never yet observed one of them flying. About midsummer one may see myriads of young ones, small copies of the parents. They are all sharpsighted and quick to move on the appearance of danger from below or above, especially from the water. It is very interesting to notice how their feet press the water into little dimples, but do not become wet and sink into it; they are clad all over with waterproof down. Many of them live over winter, mostly crawling under water in favorable localities among sunken brush and driftwood. In the spring the eggs are laid on twigs and dead grasses about the water. They live on smaller insects, but not leaving the water for that purpose.

These little oarsmen are not the only claimants of these shores. Here are other boatmen with oars, but they do not perch themselves up on long stilt-like legs, but rest their bodies flat on the water. These are the "whirligig beetles," 
Gyrinus natator. We have all seen them looking so trim and tight in their steel-blue armor, whirling about each other by means of invisible legs, or huddling together side by side in the sociable fashion. If we manage to catch one he will prove worth looking at, as much so as an elephant, when one gets his eyes open and full of curiosity to learn of everything. With a little pocket glass we may plainly see that there are two prominent beetle eyes on each side of the head. These are joined side by side, and when the beetle is on the water the lower eye is under the surface and the upper one out of water. This is a very convenient arrangement for a creature with fish enemies beneath him and bird enemies above him. Now this beetle belongs to a group of insects that are good crawlers, as a rule, but if we capture one of those "whirligigs," and let him try to walk, we will see that he cannot "get a move on him," as the boys say. His limbs have become oars and paddles and graspers.

I say they have become thus, because there is abundant evidence to show that they are descendants of beetles that lived on the land, and crawled and flew, as most of them do now. In the always hard struggle for existence the distant forefathers of the "whirligigs" came to frequent banks of streams and ponds, as good 
hunting-grounds. Much food would tempt them into the water, and then those best adapted to swim would be, through many generations, naturally preserved, and the water became their home. The eyes, although two on a side, are but one eye partitioned for two purposes. Now if we take a pin and use it carefully we can lift up the hard shining back in two plates that cover a pair of delicate and sickly wings. They are what is left of the stronger ones of its distant ancestors. They have suffered for lack of use. I have never observed one in flight, but one may see them occasionally jump in the air a few inches when alarmed from below, and then the wings are used. They are good divers. The eggs are placed end-to-end on leaves of water plants. 'The young are white or whitish grubs; these when full-grown make coccoons, or web nests, on the under sides of leaves or twigs near the water, and when their time has expired they find their way out and drop into the water. One may ask, of what use it is to know this story about a little beetle. True there is no money in it, but there is what is better than money, there is knowledge of a high order. The same power that designed and sustains these little creatures, also designed and sustains the universe. Man is "fearfully and wonderfully made," and this little insect is 
also "fearfully and wonderfully made." Enclosed in that burnished tiny shell is a complete nervous system, a complete digestive apparatus, and organs of generation for the propagation of its kind. There are delicate muscles to move the wings and legs. There is a system for the circulation of blood, organs for breathing air, and a marvellous brain to preside over all, to receive messages from the eyes and ears, and act upon the messages intelligently. The eyes are constructed of hundreds of little crystal facets or lenses on the outside, while within, the mechanism of vision is more complicated still. We do not know what such a creature has for a world. He can see and hear and feel, he can suffer from hunger and fear, he can act intelligently, he knows his kind and likes to have great numbers of them about him. He does not know much beyond his little cove or eddy, and neither do we; he soon comes to the limits of his knowledge, so do we. Our special advantage is in a wider range of intelligence, but in an infinite universe neither man nor beetle ever does more than learn a little. It is our privilege to extend our knowledge by studying this wonderful world. No greater nor grander is likely to be found anywhere, and nothing that lives is insignificant, because all are the products of infinite resources. 
This whirligig calls up another member of the family that has taken to the water. It would not require much dredging up of mire mud from the brook-bed above in the meadow to secure a specimen. He is dark brown, almost black, about three-quarters of an inch long, very round on the back, and rather thin. His legs are adapted to swimming. This is the big water beetle, Dysticus marginalis. He lives mostly under water, but he must breathe, so he comes to the surface, like a porpoise, once in a while, to get a breath, but one scarcely notices this act, as he makes but little show of himself. $\mathrm{He}$ is an insect shark, even attacking small fish. They fly from one locality to another, even miles away. The males have suckers on their fore legs very much like those on squid and devil-fish; these are to better enable them to hold their victims while eating them.

While I have been observing these "whirligigs" another fellow-mortal, who would not mind swallowing them all in a gulp or two, has been furtively showing himself from time to time from under the foam-flecked shadow of the bridge. $\mathrm{He}$ is about seven inches in length, clad in burnished scales from head to tail. His sides glisten like polished bronze, and his red fins winnow the water as he rests above the yel- 
low pebbles, and works his shining gill-plates, that maintain a current through the red network of gills by which he breathes. This is no other than our common yellow perch, Perca fluviatilis by his Latin name. If he were not so common he would be thought a marvel of beautiful colors. If one is to see him in all the glory of tints and shades, he must jerk him out of his element with a hook. He will come under a sturdy protest, with his spiny fins spread angrily abroad, like a full-rigged man-of-war with all sail set. We underrate this perch as a food fish. Good judges of such matters declare him to be an excellent pan fish. One perch lays about twenty-eight thousand eggs as large as small poppy seeds. They hatch in a few days, and in two or three years will reach an average size. The great number of eggs indicates great danger to eggs and young, and one of the most serious is from the parent fish. They will devour their own young, and would not leave one alive if they could capture them all. They know young fish make good food, but they do not know they have any young ones. Very different is this from some fish, that carry their eggs in their gills, or others, that make a nest of sticks and grass and web of their own making, and guard the eggs till they hatch, and the 
young through their feeblest stage. This species of yellow perch will, with good food and plenty of it, grow to much larger size than we see them. But now we will let him go and I will move over to the pole dam, a rod or two distant, where there is an inviting-looking puddle, cool and clear in the shadow.

It does not take a long search of an experienced eye to discover the tyrant of this miniature pond. It is not a fish nor a reptile, but an insect "scarce half made up." It is the "devil's darning-needle," or dragon-fly, one of the Libellulidoe in an undevcloped stage. So far as outward appearances are concerned, there is no hint of his future destiny, when he will course the air in burnished armor, and "down the listed sunbeam ride resplendant with steel-blue mail and shield!" We may readily see him, and study him only a few days, or even hours, it may be, before the great change overtakes him. It is a creature of about one inch in length, with two stubs of what are really wingcases on his fore back; the hinder portion of his body is grub-like, covered with a shell. There are six stout legs. The head is large, the eyes bulging, and jaws stout. We will watch him closely now and see him use a "concealed weapon" that he carries neatly tucked up 
under his chest. He is a voracious fellow, and now has his eye on a small bug resting on a bit of grass-blade. Cautiously the dragon creeps forward to within less than an inch, when he raises himself well up in front, and shoots out a bit of breast-plate material with two movable arms coming out of the forward end of it, and a sharp hook on each one of them. This instrument is hinged to the throat, folds back when not in use, and when needed is flung forward, seizing the prey in the hooks, and is by them passed to the mouth, for whose service this cruel tool is designed. If I had been in luck here this creature would have crawled out of the water into the sunshine, selected a position on a $\log$ or stick where he could get a good hold with his claws, and then wait till the sun dried his shell, when it would crack along the back; at that signal he would begin to struggle out, till in the course of a half-hour he would be clear of it. During this time his wings are constantly attempting to open, for they are wet and folded close, and if they dry in that condition all will be over with him. If there is no accident, in two hours he will be standing beside his "outgrown shell," glittering in brilliant hues, with wings delicate as a fairy's fancy might make them, and quivering responsive to 
the air that caresses them. While we admire him he launches away as if the atmosphere were his native element, and he loved the breeze and the sunshine. He left behind him, still clinging to its anchorage, the old husk with its glassy eyes reduced to transparent shards, its clutching gear folded at its breast in meek mockery, its claws deep sunk in their last grip. The past is past with this dragon forever; there will be no revisiting of his old haunts where he prowled for prey with his grappling tongs; he said no "good-bye" to his useless shroud clinging there in mimicry of life: "Let the dead bury their dead."

Thus Nature teaches us or may teach us all possible things are easily possible, and it is scarce harder to believe that even human creatures will in some way, no more wonderful, enter upon a new life for which this is a mere larval or preparatory stage. The book of Nature is writ in eloquent language, and illustrated by endless designs, and the more's the pity that "the world is so much with us getting and spending" that we do not have eyes nor ears for her lessons and her delights. 


\section{THE CAT-OWL.}

"INTELLIGENCE like our own is seen to be looking out upon us from every tuft of grass, and from every heathery knoll, from the solitudes of the forests and the shady dells."-CALDERWOOD.

THIS midwinter twilight $\mathrm{I}$ ride over the 1 clean white track, and note the changing shadows of the departing day as they deepen into darker purple along the overhanging snowdrifts, where the north wind, the "fierce artificer," has built in "frolic architecture" the endless curves of beauty. The voice of every beast and bird is hushed, the short twilight is fast disappearing, the solemn star-eyed night, with shade after shade, shuts out the distant hill and nearer wood. Like some spirit of the oncoming darkness, with stealthy wings a huge bird comes directly towards me, like a black spot slanting across the snowy background. $\mathrm{He}$ passed me with an upward swirl of his strong pinions, and turns his ugly countenance on me with a twist of his neck, and I can see the yellow-green of his eyes, the hook of his 
bill, and his cruel claws drawn up into fists and ready for action. There is no need to mistake the mission of this feathered marauder. All day long he has slept and dozed in the gloomiest retreat of yonder hemlock wood. As the day wore on the pangs of hunger grew stronger; the eyes opened wider as the fading light went out. He must have meat or he must die. No other food will keep life in him. He has glided off his perch to kill something. For that purpose is he equipped with night-seeing eyes like tigers and cats, with fierce and strong claws and tearing beak. His noiseless wings are covered with a velvet-like texture of finest feather-work. He expects to pounce on some sleeping bird or feeding rabbit. This is the cat-owl, or horned owl (Bubo virginianus). He has no need to fear any enemy but man. The whole family of them seem to represent a night side of Nature. They have never been in favor with mankind. Their solitary habits, their preference for dark places in the daytime, their murderous dispositions have all been against them, from our point of view. Pliny, the old Roman author, says of owls: "They are the very minister's of the night, neither crying nor singing clear, but uttering certain heavy groans, and if therefore they be seen 
within cities, or otherwise abroad in any place, it is not good, but foretellent some fearful misfortune." Shakespeare often introduces the owl to intensify some feature of horror or dread, and that was the prevalent feeling about them in England. Thus, in a famous play, Lady Macbeth listens to the receding steps of her husband as he goes into another room to murder King Duncan, and she exclaims, "Hark! Peace! It was the owl that shrieked, the fatal bellman which givest the stern'st good-night!" In England it is a belief in the rural districts that owl's broth is a great remedy for the cramp. Sometimes I have taken off their skins when they were too fat for comfort. The broth might be palatable. One need not be very hungry before making trial of its food qualities.

If this particular owl I mentioned does not feast on rabbit to-night, then his calculations will be upset, for he laid his course a little beyond a bit of swamp, where rabbits have their feeding-grounds. Already they are out, jumping here and there, cutting the tender twigs for food. Hark, now, to the pitiful childlike cry that rings out on the frosty air! There is a forest tragedy being enacted over there. A few more fainter screams and sobs and all is still. It was the "Passing" of poor Bunny. Life was 
sweet to him. All day he sat in a snug retreat beneath a bush, and, urged by hunger, leaped nimbly forth to fill himself with the food that no other creature wanted. I do not need to witness the performance this time to realize what it was. In an instant that great black shadow was upon him, with upraised wings and gleaming yellow eyes, and crooked, sharp, long claws driven deep into the quivering sides of his victim, that struggles in vain with such a foe. This feathered beast will fill himself, eating even the skin and bones if his appetite is keen. I have observed one devour a full-grown rabbit at a meal that lasted over an hour. One must not suppose that all this crude material goes through his digesting machinery. Nature has been very considerate in his case; he has no need to pick and cull, but bolts it down wholesale, and after an hour or two the hair and bones will be snugly put up in cartridge-like lumps, and sent back the way they came down. If this owl had not been in luck with the rabbit he would have looked sharp for a sleeping partridge, or some other bird with its head under its wing. Doubtless he sometimes hunts all night long in vain, and waits another day for a meal. I have killed one of these owls, that might have been taken for a skunk if one's nose alone was al- 
lowed to testify. Other men have had a like experience with them. I do not know whether these owls actually kill and eat skunks. I desired to get at the inside of the one that fell to my gun, to make sure about it, but a close acquaintance like that required was out of the question. It may be that they are pounced upon through a mistake, and it may be that the owl is insensible to the odor. It may be that he likes it. People are fond of musk, secreted by a species of deer, and the skunk-odor is a glandular product a trifle more pungent, and might be exactly of the desired strength to tickle the smell-sense of the cat-owl. If one could see the animals of various kinds that a single owl of this species eats in a lifetime it would be truly surprising. They subsist on birds and rabbits and inice and frogs - an average of one a day is a moderate estimate. Here and there an individual would live ten years; but for accidents and hard times they might well live twice as long. The fact that they lay but two eggs at a hatching and rear only one brood in a season is proof that they are well secured against enemies, or they would soon run out altogether. The robin lays four eggs, and brings out two broods of young, and still just holds her own; the young that reach maturity are only 
enough to fill up the ranks where the adult birds perish in one way and another. If the young owls can get through the first year they will be over the most dangerous ground, but there is a point when they demand great quantities of food and yet are not old enough to get it for themselves. The parent birds are often hard driven to furnish enough to meet their own wants, and enough for their gluttonous babies. There, doubtless, is the pinch where some of them perish. So far as we can see, there is no need to protect owls. They are a scourge on small useful birds, and a shotgun can be employed to advantage on them all. 


\section{LEDGES.}

"SPEAK to the earth and it shall teach thee."-Joв.

$\mathbf{W}^{\text {ITHIN a half mile of the main road on }}$ the way to Molega there is a sharp upraise, and a sudden turn to get over a quartzite ledge that abruptly bars the way. One may see it, like an old battered hand-made wall running off to east and west through the brackens and scrub underbrush. It is only five or six feet in height at best, and it dips or slants a little to the northward. All this steep side is more or less cracked and rent, affording rootage for rock polypod, ferns, dwarf spruce and firs, and other plants of the locality. On the more or less bare surface of this ledge, a few rods in width, there is a most interesting variety of vegetable life. There are great gray carpets of white lichens, clean and cool, and in June they are bordered with nodding lady's-slippers, or cypripediums, fashioned like daintiest shells. Slender wire-birches, clad in gray and green, stand guard over those woodland gems, that the 
sun shall not smite them, while they have their days of beautiful existence. And all the while the roots become charged with. some subtle medicament that has power to heal the shattered nerves of weary men, as the bloom has a charm to minds and hearts that love all lovely things. Let us go back to the ledge itself; flowers can have no greater interest. When we stand upon its shattered flank we are then on "bed-rock," as the miners call it, or on the "country rock," as the geologists term it. Between our feet and the other side of this globe the distance is about eight thousand miles; all the way it is some kind of solid rock or metal. The soil, the mud, and gravel, and sand, in which men plant and sow, and Nature grows her forests, is nothing more than rocks made more or less fine and mixed with some vegetable mould. This earth is really a ball of stone or mineral about as heavy as if it were iron, and it floats through space like a bubble in the air, or a toy balloon rolling over and over along the viewless track around the sun, that is fourteen hundred thousand times larger than this toy world, that can neither get away from it nor fall into it. We live on the outside, at the bottom of an ocean of air, a few miles in depth, and with us are a great many other people, 
some with two legs, some with six, some with none.

This reef or ledge is called quartzite because it is made up of grains of quartz sand that were made by rocks rolling each other on a seashore that existed before the "mountains were brought forth," before animal life existed on the naked, treeless land of the world. Time must be reckoned by many million years since the sand beach was formed that in the long run went to the making of this old ledge at our feet. One might be tempted to deny that we can know so much of its age, but careful study makes it certain that we do know. This earth is a globe for the same reasons that a dewdrop hanging on a grass-blade, or a raindrop falling through the air, is a globe. It was once liquid, and took this shape by laws of attraction, as the sun, moon, and stars did the same. All the rocks and metals were once melted; then there was no water and no atmosphere like we now have. Hydrogen and oxygen gases became chemically united, and water was the result. The first rain was warm; the first ocean covered all the earth, and was boiling hot; the steam from it cooled and returned, as rain, and was sent back, and thus the ocean was cooled. No one was there to observe all 
this, but we know it as a hunter knows where his game has been, by his tracks.

Our world had a beginning; it will have an ending. The nightly skies show pavilions of suns clustering in millions beyond the reach of all instruments. Among an endless procession of worlds ours is included. Whether this ledge of rock was begun twenty million or forty million years ago is all the same, when we consider that time had no beginning and can have no ending. We measure it by our sunshine, but if all suns were instantly quenched, time would survive. We do not alter the passage of time by stopping all the clocks, so if all suns disappeared events could transpire, although the scale of measuring their duration was lost. Eternity reaches backward as well as forward. We are never in it, because the present is neither in it nor out of it, and we only live instant by instant. So we need not scant ourselves with time in considering the geological history of the globe. We are obliged to reckon in millions of years when dealing with this subject.

If we go into the eastern part of our province, the coal mines will be there to interest you. If you do not already know, then you may readily know that the coal beds of the world are formed of leaves, branches and trunks of trees, and 
ferns. You will also learn by examining the coal, or by reading the proper books, that this vegetation grew so long ago that there was not a flower in existence, and all the plant life was flowerless, like our ferns and club mosses. This ledge is millions of years older than the coal mines. To prove this we can show that a series of rocks lies between it and the coal, and they are made up of sand that was formed on the seashore. In the Annapolis valley at Nictaux one may see these Devonian rocks packed with fossil shells. This ledge was made of rocks still older; it belongs to the very lowest or earliest of watermade rocks. The first rocks were cooled lavas, and when an ocean began to surge and break against the low sides of a crumbling crust then sand and mud were formed, and sedimentary rocks were in the making; our old ledge that runs along like an ancient rib of the earth was then begun. The sullen waves in ceaseless action reduced the shore lines to material that the undertow and tides carried backward, where it fell to the bottom, and by natural action of gravity and elements was assorted in strata or layers of coarse sand and fine muds; one to form quartzite like the ledge, the other to form slates that we find exposed or hidden running beside them.

If this earth were a dead body, an unmoving 
thing, that never shrunk, and shivered and shook, and groaned, and tilted up and down, then these layers of mud and sand would have remained flat on the floor of the ocean, and there would be no ledge for us to observe and discuss. But quite otherwise is the truth.

A very shaky affair is our old planet. It is cracked and mended in millions of places; wherever a quartz vein exists there was once a rent. The rocky crests of the loftiest mountains are often gleaming with imbedded fossil shells, that were ocean-born. Deep down in the great mines one hears the groaning of the mighty strata of rocks. This is a cooling planet, and as it cools it shrinks, and the hard crust rises in great crumples of mountain ranges. On a small scale, a baked apple is wrinkled; the inside has become smaller, while the skin has not shrunken. During this shrinkage our infant ledge was, with all the adjoining rocks, pushed sidewise into waves or crumples, thus forcing what was once a flat surface of rock into various slants or angles, and at the same time pushing them out of water. Through many million years the agencies of air and atmosphere, and heat and cold, and ice, and mighty glaciers and running waters, have worn away the highest parts of the ridges, and left the hardest portions tipped on edge by the 
shrinkage of the globe, and shining grim and gaunt above the kindly attempt of Nature to cover it with the leaves and flowers of a later world.

Here, then, is a most interesting antiquity. It is crowded with inscriptions, written all over with the records of past ages. To be able to read them gives an added charm to life, and the time to give to such lessons is so far from lost that it is devoted to an elevated and worthy task. 


\section{BATS.}

"IF indeed thy heart were right, then would every creature be to thee a mirror of life, a book of holy doctrine." - Tromas $\boldsymbol{\lambda}$ KEMPIs.

THIS midsummer evening a bat flitted out 1 of the shadow, dodging hither and thither after the manner of his kind. I doubt if there is another animal common to our country so often seen and about which so little is generally known. It is all the more surprising when we consider what a truly wonderful creature it is. On the wing nothing is more agile, on the ground it is helplessness personified. Birds and insects can fly, but they can also walk or hop, or run or crawl, but a bat can do no more than hitch himself along on his foreelbows and hinder feet. When at rest he neither lies down, nor sits up, nor goes to roost, but he hangs himself up by his thumb-nails and rests his body in the slack of his wings. He has been a puzzle to people, who could not make out where he belongs in the animal king- 
dom. In the Mosaic law he is classed with birds: "The stork and heron, the lapwing and the bat," all unclean (Lev. 11: 19). But bird he certainly is not, neither is he nearly related to birds. The Arabs, a kindred people to the Jews, call it Gessim-al-sheytan, meaning "devil's bird." The Germans call it Fledermaus, or "flying mouse." Always a creature of ill omen. Among the Greeks it was sacred to Proserpine, the queen of hell. Among the old Norse or Northmen it figures in their literature as a messenger of the Goddess of Darkness and Death. Painters always use the wings of bats for the Devil and his imps, and the wings of birds for angels, - not that there is any good reason for the choice, beyond the general dislike of the bats.

As a rule they are not only harmless but of no small service to mankind, for they live on insects, which they destroy in great numbers. I say as a rule, for there are bats in South America that alight on cattle and even sleeping people, and bite till the blood starts, and fill themselves with it. In the Islands of the Eastern Ocean - Java and Batavia - there are fruit-eating bats, looking not unlike foxes and as large as a cat, with wings measuring four feet from tip to tip. They are fond of bananas 
and prove very destructive to plantations. There are about four hundred species known to science. They are to be found in all climates, even where it is much colder than in Nova Scotia. During the cold season, of fully six months, they congregate in caves, hanging to the roof in great bunches, where they have been found in midwinter white with frost but unfrozen and alive. With us they pass the winter in old buildings where they can hide under the finish, also in hollow trees, and holes among rocks, etc. It is truly wonderful that they are not frozen in such localities, where the temperature must be often many degrees below freezing. Old Nature knows the way, and these curious animals, slung in their wings, sleep on during half a year, without fuel or nourishment, and awake to renew the perils and pleasures of an existence that would hardly seem worth the having.

It will be worth the study to examine the wing structure of a bat. The wings of a bird are constructed on the two fore limbs. They are arms and wrists and fingers with quills and feathers on them. Until the wrist is reached the bones are very much like our own, the fingers are soldered together, and on them are supported the long quills. From the wrist to 
the elbow the secondary quills are merely glued or stuck at the very ends to the arm bone, the ulna. The thumb appears as a hook in some birds; in others it has an outgrowth of a short quill, "a spurious primary." Now the wing of a bat is arranged on a fore leg or a fore arm, but on a different plan from the bird. The five fingers are very long, and between them is stretched a most delicate membrane, that extends backward around the body from both sides of it, and takes in the hinder legs and tail in all insect-eating bats. Fruit-eating bats, in some instances, do not have the wings extending backward to the tail.

There is no other animal with such an arrangement for flight. In the far East there is a tree-frog with very long toes on all four feet, and these, being webbed, are used not for swimming, nor properly for flying, but as aids to jumping, like our so-called flying-squirrel. When this frog desires to jump from one tree to another within range, he makes the leap, spreads his legs and toes, and glides forward and downward; but this is not true flying. Our bat is an expert on the wing; no bird is quite his equal when it comes to short turns, as any one knows who has tried to bring one down in a room. The wings are richly supplied with 
nerves, and are sensitive to a degree that we can hardly imagine. Through that means the animal feels the presence of near objects even in dark rooms and caves, and avoids them. Probably there is a sensible difference in the air currents near any object. Many species of bats have peculiar leaf-like structures growing straight up from the end of the nose, and these are thought to be feelers.

It is well known that bats live upon flying bugs and beetles that are out for an airing at night. It is also a common saying, "Blind as a bat." Now, if a bat is blind, how does he manage to find his food in the dusky twilight, and even in the dark? The fact is he has very keen sight, and also very sensitive wings, to tell him if he has run against any living thing that may serve as food. I think it is not generally known how they are captured. The mouth is sinall; there are no hands, no bill, nothing, apparently, to aid in capturing his prey. $\mathrm{He}$ makes a net of his wings, he draws his tail well under him when about to take an insect, thus forming a bag, and the insect is run down and run into it, and then seized and eaten. One may readily observe them do this; they halt in a hurried, scuffing way and then go on for more. When one considers that they have no nests to 
lie down in, no roosts to sit on, then the matter of caring for their young becomes a curious problem. I will try to explain : Two are generally born at a birth ; they are very small, helpless creatures. The mother places them at her breasts, and they cling to her hair with the hinder claws and thumb hooks, and there they remain till they are able to fly. By some naturalists it is stated that the male bats assist in carrying the young, but this is very likely a mistake, as they could not feed them. Some tropical bats are almost without hair, but they have pockets or pouches in which the young are carried, as they could not cling to them. The next time one of my readers runs screaming away from one of our harmless little bats let her take a second thought of this tiny fellowcreature, so fearfully and wonderfully made, so richly endowed with motherly feeling, so tenderly cared for by a Providence that overlooks no living thing, and marks a sparrow's fall or a planet's birth. Much more than I have set down is to be learned of the habits of these animals.

They are not at all related to mice. Their teeth are near to the moles. For a very long time they have been in the world. Their fossil remains are found in rocks whose origin was 
many million years ago. They clustered in the twilight and captured their prey ages before man came on this earth. Some time, doubtless, the earlier rocks will reveal the remains of their immediate ancestry, which is not now known.

In all these chapters I take it for granted that all our forms of life are outgrowths from older and different forms. There are about ten million different species of animal and vegetable life now known to science, and there are vast numbers of microbes that are visible only with the best microscopes. All observation and reasoning warrant the belief that there were not ten million separate creations, but they are the varied branches from one or a few original living creatures of simple structure. We can say with certainty that all naturalists take that view of the matter, because it explains numerous difficulties, and harmonizes conflicting phenomena. 


\section{BY THE RIVERSIDE.}

"THE earth is all enchanted ground. With its light and shade, its ebb and flow, it is all thine."- PARsEe SCRIPTUREs.

WITHIN a mile or more of the gold mines on this road of many marvels there is a bridge crossing the Wildeat River. This is a brisk stream, forty or fifty feet in width at this point, but a few rods below it opens into a large pond, where the white and yellow lilies grow, where the wild ducks feed, and the swallows skim its gleaming surface.

I have halted here this October afternoon because many things invited me, and there was no good reason why I should not accept the invitations. There are no lovelier days in all the year than these. June has its peculiar charms of unrolling leaves, of white banners on the wild-pear trees, and all the promise of flower and fruit, but October is the realization of the promise. The barns are filled, the meadows are picturesque with stacks of hay peeping out of the alders and red-leaved maples, 
like domes of Eastern temples in a picture landscape.

In these early sunny days of the month the atmosphere is perfect, the light is softened and tempered by the tints and colors of ripened foliage. Thistles and milkweeds have sent their winged seeds on the friendly winds to be sown far and wide, to improve their chances for life; and now, looking into the sunbeam, one sees these silken voyagers loitering and playing with the zephyrs, till the dew-damp air saturates their wings and they come to earth, perchance to germ and grow, perchance to perish.

Amid all this autumn ripeness here is our witch-hazel, Hamamelis virginianus, tricked out in the bravery of yellow flowers, growing on the same branches with the nut-like seeds and fading leaves. I think this curiosity is generally unobserved. The blossom is rather a curious or exceptional make-up, but it is pretty in color and dainty in structure. A calyx or cup notched on the rim holds a tiny boquet of four strap-shaped petals, and eight stamens, and two styles.

This late display of blossoms is only getting ready for an early start in the spring. Then all the seed will be set, and may proceed to grow 
at once. All our trees that are not evergreens make preparations for the new leaves, in buds stored with food, and often varnished over, as if each one was an object of special providence. Our mayflowers, or trailing arbutus, produce the flower buds in the autumn, and sometimes these preparations for the next spring are pushed too far by favoring weather; and then one finds here and there a fall blossom, born out of due season, instead of being tucked up under a snow blanket in a sound sleep of months.

This witch-hazel with us never grows to more than ten feet in height, but in the Southern States it is much taller. It is an old belief that rods of hazel had magic powers, and so far is this from being outgrown that $I$ have seen a sane practical farmer searching for gold mines by the aid of a hazel crotch, and he called it a "mineral rod." What the rod did not do in the way of "drawing" his imagination helped out. He never found a mine with its aid, but he did not lose confidence in the stick - to do that would be to drop a superstition, and that kind of a devil does not quit short of "fasting and prayer." So far as we know, this belief is of the remotest antiquity.

The earliest written history of Greeks, Romans, 
Hebrews and Egyptians relates something of magic rods, and certain kinds of woods were believed to have superior virtues. The Greeks and Romans and Germanic peoples used them in their search for metals. Our Bible makes frequent references to them and their magic properties; they are mentioned as tokens of power, as the "rod of mine anger" and "thy rod and thy staff, they comfort me."

However, I must not dwell on this tempting subject, where so much of interest might be written. Here there are many other things most worthy of special notice. Plants and trees, as we all know, have their proper preferences and places of growth. Some grow under water altogether, some grow partly in and partly out, and others hold to the damp margins, and others, again, the swamps and drier uplands. Here within a few rods are great varieties of soil where trees and shrubs and grasses may manage to grow. But always there is crowding, and hard struggle for existence. Nature sows her seeds by the thousand to get one to grow and reproduce its kind. Sometimes they are cast on the ground and quickly covered with leaves, and thus shut out from proper heat they long remain waiting for a day of germination. Many seasons may pass away, and yet they are 
in some sense still alive. After two thousand years buried seeds have germinated and grown. On our own forest lands, when the old growth is burnt over, a new one of a different character springs up. They are from seeds deep buried in the mould, where the fire did not reach them. Wild cherries are common in such second growths; the seeds have been dropped by birds that had eaten the fruit - and just here let us say that all the eatable part of the cherries was Nature's plan to get the seeds cast abroad. By this means the birds are made to do her work; she offers the palatable juicy pulp to the birds that swallow it and then carry the seed away. Thus with all fruits and berries, they were not produced by the trees and shrubs that grew on this earth before birds appeared. There were no birds when the great forests grew through millions of years that furnished the material for coal mines. Birds and berries came along together in the order of creation, as we read from the fossil history of once living forms. The first true seeds were naked seeds. Nature never exactly repeats herself - the thing "that hath been " will never exactly be again; so there must be immense variety; and some seeds will have a covering worth eating, and if they do hungry birds will try their qualities; it will be 
then that the seeds with the most toothsome peel and pulp will be surest to get swallowed. Now the naked seeds are digestible in birds and form a great portion of their food, but the seeds of berries and fruits are not digestible. They are able to withstand the digestive action. At the first this was probably true of only a few out of many, but the tough ones got themselves planted, and brought forth after their kind according to law. Sparrows and all seed-eating birds eat the seed for food, while thrushes and all other berry-eating birds swallow the berries, seed and all, for the sake of the pulp.

But let us return from this tempting by-path to the riverside. Here on the plashy brink, crowded among the small stones is the common "blue flag," to call it by a common name. It is the Iris virginica of science, and the Flowerde-luce or Fleur-de-lis of heraldry and sentiment. I am too late to salute the beautiful flowers where they bloomed a few weeks ago on the slender stalks that upheld them like staves of royal banners, and now overloaded with the clumsy seed vessels, that will keep their hold the winter long. If the flower were not so common it would be considered one of the most beautiful and curionsly constructed of all our 
flora. Longfellow taking this gem for a theme gave us one of his most pleasing poems. I cannot find place for it all, but here are given a few stanzas :

"Beautiful lily, dwelling by still rivers Or sheltering mere, Or where the sluggish meadow-brook delivers Its waters to the weir.

"Born in the purple, born to joy and pleasance, Thou dost not toil nor spin, But makest glad and radiant with thy presence The meadow and the lin.

"O flower-de-luce, bloom on and let the river Linger to kiss thy feet !

0 flower of song, bloom on and make forever The world more fair and sweet!"

The poet calls this flower a lily, which it is not; but there has been a good deal of confusion about it in song and story, where it is often termed a lily. Fleur-de-lis is a corruption from Fleur-de-Louis, for Louis VII of France chose it as his heraldic emblem when he went on his crusade to the Holy Land. We have also a white variety growing here and there among the blue. I do not think it is to be reckoned as a species, although it is surely well on the way to that distinction. The root of the blue flag is used in medicine, but I do not know 
if that is any reason for supposing that it has any curative properties. However, the world is "more fair and sweet" by its dainty charms above ground, and we will not dig for its hidden virtues.

Within a few feet of the flags, a gravelly, dry bank comes abruptly to the stream, grows a shrub worthy a longer notice than can be given it here. I refer to the bayberry, Myrica cerifera. It is pleasant to the eye, with its cool gray stems and branches and its glossy green leaves. It is grateful to the sense of sinell; so clean and aromatic that pillows filled with the leaves are delicious soothers of tired nerves and weary cares. The flowers are very small, and only to be seen by looking for them, but the seeds, which are hard-shelled, are covered with a vegetable wax. They are gathered in bunches close to the branches and well hidden by the clustering leaves. Our older settlers here, and in New England often gathered these "wax berries," or bayberries, and boiled them till the wax floated, when it was cooled, and made into candles. Four pounds of berries would yield about one pound of wax of a greenish tinge and a pleasant odor. 'This was also made into soap. It is still used, and may be purchased at wellfurnished drug stores. 
A close cousin of the bayberry is keeping it company here, the "sweet fern," Myrica aspleni folium. It, too, is blessed with a healthy fragrance through all its leaves that outlasts the life of them. They seem to have been all their days gathering in, by some cunning chemistry, the pungent aroma of the wayward winds and the kindly soil. The bark, and twigs, and leaves are rich in the material serviceable for tanning purposes. It is not a showy shrub, neither is it of much service to man, but it is a pleasing feature of nature, growing in waste places, covering unsightly surfaces with restful green and gracious influences.

Here this chapter must come to a close without more than a glance here and there, where one might linger long with profit if he loves the life, and varied aspects in which the Maker of all has made his presence known. 


\title{
THE RED SQUIRREL.
}

\author{
"I LIE abstracted and hear beautiful tales of \\ things and the reasons of things ; \\ They are so beautiful, I nudge myself to \\ listen." - WALT WhITMAN.
}

TIS morning, in the month of February, the air is still, the trees crack, the snow gives way under the sleigh with a distinct crunch. All sounds are easily heard. The chirp of a kinglet the call of the chickadee, the tapping of the woodpecker, break the stillness as if all the world was dead beside. Almost within reach of my arm, perched on the end of a fir limb, is a red squirrel, or pine squirrel, or chickaree, or Sciurus hudsonius. By all these names he is known. His winter coat shows to advantage, the long hair on the ears especially, and somewhat longer on the whole body than in summer, is silver-tipped with frost. $\mathrm{He}$ is making his breakfast on the tender frozen ends of the branch on which he is seated. My heart is touched by his misfortune. Only a few months ago he was 
revelling in berries, and nuts, and eggs, his coat was glossy, his tail aloft, and life seemed a frolic and all the world made for him and his. No glimpse of this dreary morning clouded his day of sunshine. Now he has got down to the hard realities of life. Such a breakfast is a notice to all beholders that winter is pressing him sore, and it is at the same time an exhibition of his intelligent ability to meet an emergency. There is nothing very nourishing in fir brush however filling it may be, but enough of it will sustain life, and that is the pinch where our little "fellow-mortal" is caught. When he is driven out of a warm bed by grim hunger, and obliged to face a temperature below zero, and look out on a world covered with snow, and no pine cones in store, then he must find something that will answer for food, or die. There is plenty of fir, and porcupines and rabbits subsist, during the winter, very largely on the bark of trees, but they have inside arrangements to accommodate and digest great quantities after the fashion of cattle; by eating a deal of crude material they extract enough to nourish their bodies. Quite otherwise with our little squirrel, his digestive organs are adapted to deal with food in concentrated forms of seeds, and berries, and eggs, and young birds. One beech-nut is worth more for 
food than twenty times its weight in fir twigs. This ability to tide over a famine with his eyes open is one proof of the red squirrel's high rank in squirrel intelligence. He stands at the head of a large family to be found all over the world excepting Australia, Madagascar, aud the Polar regions. With some minor differences of shades of color, and slight variations of markings, our squirrels may be found from Nova Scotia to British Columbia, from Hudson's Bay to the mountains of the Southern States. They are near relations of the gophers and prairie dogs, and woodchucks or ground-hogs. The prairie dogs and woodchucks are grass-eating, burrowing, winter-sleeping, slow, stupid creatures in comparison with these pine squirrels, who have descended from a parent stock of the woodchuck type. The ability to climb a tree quickly, to be agile and nimble, to use the front feet for hands, and secure the best food in small quantities are all developments in the line of intelligence. In the common striped squirrel we have a creature midway in the upward journey; he is vastly nearer to the parent stock, he lives in dens of his own making under ground, he sleeps through the winter; he can climb a tree but not nimbly, he prefers the ground and only climbs for food occasionally. If hard pressed by dogs 
or boys he will take refuge in a tree, but he is uneasy and soon makes a dash for liberty down the trunk, in the maddest defiance of danger that often ends in death. Only in his den or some dark hole does he feel safe. On the branches he is clumsy and easily shaken down. Not so our red squirrel : he loves the trees. Just watch him as he makes his way from limb to limb in the forests, swiftly and surely, till one must run to keep up with his movements. On the ground he is quick and sprightly, and on a fence next to a tree he can show to advantage all his best points. He fearlessly and swiftly swims a river, and makes use of a chip or any bit of floating wood for a raft if it comes in his reach. I have paddled my birch canoe across the course of a swimming squirrel; quick as a flash he sprang into it and over it and made for the shore again. Thus we see that he is an allround fellow, - on the ground, in the water, on the trees he is at home. He looks the bright, smart chap that he is. He challenges me in the forest from a lofty perch with a saucy call, and then begins to jerk himself down the tree to make a nearer acquaintance, till of a sudden he turns with a cry of alarm and scurries back to his perch, only to repeat that performance as long as one likes to watch him. His 
intelligent euriosity prompts him to a close jnterview, but his fears defeat his well-meant intentions.

I have mentioned that our squirrel was driven to eat fir browse when his stock of stored-up cones was exhausted - and thereby hangs a pretty tale if I can manage to tell it aright:

In the early autumn, the last of September, or even a little earlier, whoever will go into the pine forests will soon find that the red squirrels are cutting off the cones that grow on the upper branches and allowing them to drop. After working at that for a while they come down and carry them away and hide them under old logs and stumps and roots; and once I saw one stowing them by the half-bushel in a waterhole where he had built quite a little wharf in that way, taking some pains to put them in place.

If we examine the cones at this time they will be found to have a seed under each scale, excepting near the small end of the cone. It will be seen that the cone itself is but a protecting growth to cover the seed - each one for itself; and the pine has no other intention than to get the seeds ripe and let the winds sow them. At this green stage the seeds are filler with a milky juice containing all the nourishing ele- 
ments wherewith to feed the seedling pine at the outset of life. Had the squirrels waited till the seed ripened the opportunity to get any would have been lost, for then the protecting scales dry and curl up, allowing the seeds to escape; and each one is provided with a wing, and as it falls the winds drift it away from the parent tree, where, perchance, some better condition of light or soil awaits its coming. So it turns out that the cone has been cut in the very nick of time, if it is to be had at all when the seeds in it are good. Not only that, but to store it in damp places is the right thing to do, for it never shrivels up there. The turpentine in it and on it prevents decay, and the seed hardens and will remain sound and sweet during more than one season. When the snow covers all the land these squirrels almost entirely live on the stores of cones. They will burrow down through two or three feet of snow to their treasures and come up with their breakfasts in their mouths. The cutting of these unripe cones and they do the same by spruce and fir - and storing them in proper damp places for a winter that many of them have never experienced is a very interesting example of what is called "instinct," and by that word we generally mean an implanted sense, a natural mechanical disposi- 
tion or inclination to do the best thing for itself without thinking at all. In that case we may inquire if this instinct was revealed to the first pair of squirrels of this species, and has passed by inheritance ever since to all of them, or is it imparted after birth to each individual? If we can get at the bottom facts this instance of instinct may be explained in a natural way, but many other instances thus far have had no solution. It will be found that our squirrels have inherited a habit of their ancestors. But what about their ancestors? How did they acquire the habit? The first fact of prime importance in the study of all living things is the hard struggle for existence that all forms of life must surely meet. To get clear of being eaten and find something to eat have always been the chief aims of animal life. Hunger is a sharp demand that cannot be long delayed, or death will claim a victim; but there are always more mouths than morsels; by far the larger portion of all lower animals produced are either eaten by other animals, or they starve to death. Throw to a flock of hens a handful or two of bits of bread and notice, if they are hungry, how eagerly they contend, and how each one tries to secure the largest piece in her bill and run away to a place where she can eat it 
securely alone. In the sharp competition for food everywhere prevailing many have been the plans and devices to secure it, to keep it, to use it to the best purpose. Mankind has often stumbled by accident upon discoveries and inventions that have proved of great service, and doubtless in the animal world below him the same thing las occurred. If an animal were to hide a portion of food not then needed, it would be an act that might save his life, and, if it became a habit in his descendants, might preserve the species to which he belonged. As a matter of fact, many meat-eating animals do hide portions of their food not needed at that time. We have all seen or known of dogs burying meat bones for future use, and weasels and other creatures do the same. I have seen a tame crow hide portions of food, even covering them with a chip, and taking much pains to do it well. Very often he did not return for it, because he had an abundance elsewhere. His act was an inherited habit, the surplus bit of food suggested and prompted the hiding it. This habit, or now called instinct, of hiding or storing food by animals may have originated accidentally. Any ravenous, hungry creature seizing his portion, or a good deal more, and running, as the hens do, to a plice of safety, would 
try to get out of sight and hearing of others. From hiding himself and his booty it is not a long step to more or less cover up what he could not then eat. To hide it from eyes would not be so important to him as to hide it from noses. Smelling was more to be feared than seeing; to bury it would seem to the owner the way to best protect it. Such a habit would be of immense benefit to the possesser of it. Such habit could be easily formed, it seems to me. It is certain that different families of animals practise it and profit by it. A good instance of it in birds may be seen in the California woodpeekers. In the autumn they make small shallow holes in the thick bark of pine-trees; into each one they crowd an acorn till it is about level with the bark. I have seen hundreds of them on a single tree. These woodpeckers do not, as a rule, eat acorns. I have watched in vain to see them do it. The explanation is probably to be found by referring the habit to distant ancestors, not yet fully woodpeckers, who did store acorns for food, and to them it was of great value. 'The liabit has outlasted its use.

The squirrel family and their near relatives the gophers are noted for carrying away stores for future use, and our striped squirrels do the 
same. Our red squirrel keeps up a family habit when he lays aside something he may need further on in the season; but how does he come to cut and hide the cones before the seeds in them are ripe, but just in the " nick of time," if he is to get them at all? Let us consider the case. The coues hang tips downward from the ends of the branches. When the seeds are ripe the scales over them become dry and curl upward, and the winds toss the branches, and the winged seeds fall out during the highest winds and are scattered wide away. Now it is clear that the squirrel could not get the ripe seeds; before that could be done he must cut away the cone. But there he is met with a difficulty: the seeds do not ripen and all get clear on the same day out of a cone. The scales near the small end curl up first. There is no proper time to cut a ripe one and secure more than a very small portion of the seeds. Searching for food very long ago in squirrel history they put their teeth into the green cone, and discovered the juicy seeds and ate them. What they did not need they hid away, as they would do with some other food, and the habit was of so much value that the squirrels who did that were able to live over winter in pine forests. Our squirrels now do by inherited habit what was acquired by other gen- 
erations. They hide in damp places because they are the most numerous and convenient localities for storage purposes.

To get back to our squirrel making his breakfast on browse. I had never noticed before how useful his tail was on a cold morning. It was drawn tight over his back to make the most of it for a blanket. To see him in frolicsome mood in the summer one would think he considered his tail a mere plaything to be flirted and whisked for fun. When he curls up in his nest his tail is made to do duty for bed-clothing. A very serious charge lies at our red squirrel's door: he is a bold bad robber of birds' nests, eating eggs or young with great relish. All our small birds are unable to drive him away, and their young become victims to his appetite. I was witness to an attempt on a robin's nest that was built on the end of a birch limb about thirty feet from the ground. The outery of the pair of birds attracted my attention. The squirrel was within six feet of the nest, hitching along in short jerks, while the indignant birds almost alighted on his back. At last one of them made a desperate drive at him and knocked him off the limb. He made himself as flat as a pancake, and although he struck on a granite boulder he scurried away at once. This ability to fall from 
a long distance unhurt is a peculiar trick of the tree squirrels.

While I am amused and interested in the red squirrel, and would not like to see them exterminated, still it must be admitted that through their ravages on useful birds they are not a desirable part of our population so far as bread and butter are concerned. But the forests and roadsides would lose a very pretty feature if this nimble bright animal was taken away. $\mathrm{He}$ doubtless has his " inalienable " rights to live and be as happy as he can, or he would not be at all. Everything was not made for us, and for our use. We are at the head of the class, but that gives us no title to put all others below us under our feet. Our boasted superiority is, after all, only in mental and moral directions. The foxes and deer have keener sense of smell than we have, birds have better eyes, and superior means of locomotion, spiders sling their wheel nets like trained engineers, fishes return from ocean voyages to their own rivers, birds fly from the Arctic to the Torrid zones with no other guide than their own natural ability, bees and ants organize into governments ; and so one might go on to show that all the mind in this world is not in mankind. The squirrel knows his little world of trees and fences, and old stumps and 
hollow logs, and where nuts are to be found and toadstools grow, he knows the common birds and beasts by sight, as a dumb person knows them without names, he plans and acts in such ways as each day has needs, he does not know beyond the limits of his wanderings. We too are soon lost. Begin where we will to study, to investigate, and directly we arrive at the boundary of all human knowledge in that direction, and can only say, with the apostle of old, "God knows, I cannot tell." 


\section{BIRDS.}

"THE birds, great Nature's happy commoners." - Rowk.

"The poetry of earth is never dead." - KEATs.

A MONG the many attractions to a natural$A$ ist on the Molega Road are the birds. To pass over them without notice in these studies would be an ungracious act on my part. Often enough my drives would have been lacking in some special feature of interest had it not been for my feathered acquaintances. I am painfully aware that the general run of people do not give much attention to birds. Residents of the country districts, although in the midst of good opportunities, seldom know even the names of common birds. They recognize swallows, partridges, owls, woodpeckers, chickadees, sparrows and hawks; but these are family names, and it is rather a loose-jointed kind of knowledge that does not go any farther than that. I am not of the opinion that it is an easy matter to learn the names of all or even half of our birds. It requires enthusiastic interest, books and speci- 
mens, and much perseverance. Still it is quite desirable that knowledge increase in this direction. It is not realized that for the most part birds are so useful that we could not hold our own against insects without them. We would surely be driven out of the land by caterpillars, grubs and bugs, and beetles and flies, if our feathered allies did not destroy them by millious every day, even within the area of one small county. Long ages before mankind appeared on this earth birds were here. Their fossil remains imbedded in the ancient rocks proves this statement beyond question. It is then very evident that they can live without us, but without them human existence could only be maintained within narrow limits. No grains could be grown, no trees could live. The insect-eating birds are to mankind what the embankments that keep back the ocean are to Holland. If the wall was removed or broken down the whole country would be overwhelmed with water. Insects destructive to vegetable and animal life exist in countless species, and their ability to multiply their numbers even in one year is something incredible. They are held in check by birds. There are other agencies that help in this direction, but they would prove unequal 
to the work, and to the birds we owe a great consideration.

I am thinking that some readers with naturalist's taste may turn over these pages for information and recreation, and it is my aim that something of both may be found here.

To begin with the information, I set down a list of such birds as one with good eyes and ears for them would identify in the course of two or three years, making about four trips a week with an old horse and plenty of time and enthusiasm over the Molega Road:

\section{Thrushes.}

Hermit Thrush, or Swamp Robin, Turdus analaska. Olive-backed Thrush, Turdus ustulatus.

Robin, Merula migratorius.

Cat-bird, Galeoscoptes carolinensis.

\section{WARBLERS.}

Summer Yellow Bird, Dendroica astiva.

Black-throated Green Warbler, Dendroica virens.

Black-throated Blue Warbler, Dendroica cerulesens.

Black-polled Warbler, Dendroica coronata.

Chestnut-sided Warbler, Dendroica pennsylvanica. Bay-breasted Warbler, Dendroica castanenea.

Cape May Warbler, Dendroica tigrina.

Black-and-Yellow Warbler, Dendroica maculosa.

Yellow Red-Poll Warbler, Dendroica palmarum. 
Blackburn's Warbler, Dendroica blackburnia. Common.

Pine Creeping Warbler, Dendroica vigorsii. Common.

Maryland Yellow-throated Warbler, Geothlypis trichas. Common.

Mourning Warbler, Geothlypis philadelphia. Rare.

Connecticut Warbler, Geothlypis agilis. Very rare.

Nashville Warbler, Helminthophaga ruficapilla. Fairly common.

Tennessee Warbler, Helminthophaga peregrina. Rare. Canadian Flycatching Warbler, Sylvania canadensis. Not rare.

American Redstart, Setophaga ruticella. Very common.

Black and White Creeping Warbler, Mniotilta varia. Abundant.

Black-capped Flycatching Warbler, Sylvania pusilla. Rare.

Northern Parula Warbler, Comsothlypis americana usnere. Common.

\section{VIREOS.}

Red-eyed Vireo, Vireo olivaceous. Very abundant. Solitary Vireo, Vireo solitarius. Common. Yellow-throated Vireo, Vireo flavifrons. Rare.

Sparrows, Finches, Etc. Song Sparrow, Melospiza fasciata. Very abundant. Swamp Sparrow, Melospiza georgiana. Common. 
Snow Sparrow ("Blue Bird "), Junco hiemalis. Very common.

English Sparrow, Passer domesticus. Too common.

Eastern Fox Sparrow, Passerella illiaca. Common sometimes.

Tree Sparrow, Spizella monticolo. Common in winter.

Chipping Sparrow, Spizella socialis. Rare.

White-throated Sparrow, Zonotrichia albicollis. Particularly abundant on this road.

Rose-breasted Grosbeak, Habia ludovicianus. Common.

Pine Grosbeak, Pinicola enucleator. Common.

Snow Bunting, Plectrophanes nivalis. Common in winter.

American Crossbill, Loxia curvirostra. Common in winter and spring.

White-winged Crossbill, Loxia leucoptera. Quite common.

Pine Finch, or Siskin, Spinus pinus. Common, not in summer.

Red-poll Linnet, Acanthis linaria. Common in winter.

Lapland Longspur, Calcarius lapponicus. Occasional. Purple Finch, Carpodacus purpursus. Very abundant.

American Goldfinch, Spinus tristis. Quite common.

Flycatchers.

Water Pewee, Sayornis phobe. Rare. Olive-sided Flycatcher, Contopus borealis. Common. 
Kingbird, Tyrannus tyrannus. Very abundant.

Traill's Flycatcher, Empidonax traillii. Not very common.

Least Flycatcher, Empidonax minimus. Common.

Wood Pewee, Contopus virens. Common.

Yellow-bellied Flycatcher, Empidonax flaviventris. Rare.

WOODPECKERS.

Hairy Woodpecker, Dryobates villosus. Common. Downy Woodpecker, Dryobates pubescens. Common. Yellow-bellied Woodpecker, Sphyrapicus varius. Common.

Flicker Golden-winged Woodpecker, Colaptes auratus. Common.

Pileated Woodpecker ("Woodcock”), Ceophlous pileatus. Rare.

Arctic Three-toed Woodpecker, Picoides arcticus. Rare.

American Three-toed Woodpecker, Picoides americanus. Rare.

Kingfisher, Ceryle alcyon. Common.

Black-billed Cuckoo, Coccyzus erythrophthalmus. Fairly common.

Crow, Corvus frugivorus. Abundant. Raven, Corvus corax. Somewhat rare. Blue Jay, Cyanocitta cristata. Very abundant. Canada Jay ("Meat Bird"), Periosoreus canadensis. Common.

Rusty Blackbird, Scoleocophagus carolinus. Very common. 
Cow-pen Bird, Molothrus ater. Rare.

Butcher Bird, Lanius borealis. Rare.

Cedar Bird, Ampelis cedrorum. Common.

Ruffed Grouse, Bonasa umbellus. Common.

Spruce Grouse, Tetrao canadensis. Rare.

Cliff Swallow (Eaves Swallow), Petrochelidon lunifrons. Very common.

Barn Swallow, Chelidon erythrogastra. Common. "Stump Swallow," Tachycineata bicolor. Common. Ruby-throated Hummer, Trochilus colubris. Common. Night-Hawk, Chordeiles virginianus. Abundant. Chimney Swift, Chatura pelagica. Very abundant. Blue Bird, Sialia sialis. Very rare.

Golden-crowned Kinglet, Regulus calendulus. Abundant.

Ruby-crowned Kinglet, Regulus satrapa. Common. Black-capped Chickadee, Parus atricapillus. Very abundant.

Hudsonian Chickadee, Parus hudsonicus. Rare.

White-breasted Nuthatch, Sitta carolinensis. Common.

Red-breasted Nuthatch, Sitta canadensis. Common. Brown Creeper, Certhia familiaris. Common.

\section{Hawks.}

Sharp-shinned Hawk, Accipiter fuscus. Not very common.

Cooper's Hawk, Accipiter cooperii. Rare.

American Goshawk, Astur atricapillus. Rather rare. Marsh Hawk, Circus hudsonius. Fairly common. 
Sparrow Hawk, Falco sparverius. Common. Pigeon Hawk, Falco columbarius. Rare. Red-tailed Buzzard, Buteo borealis. Common. Broad-winged Buzzard, Buteo pennsylvanicus. Rare. Fish Hawk, Pandion haliatus. Common.

\section{Owes.}

Great-horned Owl, Bubo virginianus. Common. Barred Owl, Syrnium nebulosum. Common.

Saw-whet Owl, Nyctale acadica. Not common.

\section{Herons.}

Great Blue Heron ("Crane"), Ardea herodias. Common.

American Bittern (Stake-driver), Botaurus lentigionsus. Common.

Shore Birds, Etc.

Spotted Sandpiper, Actitis macularia. Common.

Least Sandpiper, Tringa minutilla. Common.

American Woodcock, Philohela minor. Fairly common.

Black Duck, Anas obscura. Common.

Wild Goose, Branta canadensis.

Wood Duck (Summer Duck), Aix sponsa. Common in the fall.

American Whistler Duck, Glaucionetta clangula. Common.

Shelldrake, Merganser americana. Common.

Herring Gull, Laxus argentatus. Occasional.

Loon, Urinator imber. Common. 
Here then are one hundred and fourteen species. The list could be enlarged by taking in the lakes and some other features of the district, which is twenty-seven miles from the seacoast, where, of course, numerous additions could be made of beach and ocean birds. Among so many as I have named, one comes as a matter of course to have his favorites, but all are interesting. Some of them are delightful songsters, others are almost dumb, and others, again, are harsh screamers. The swamp-robin, or hermitthrush, is the most charming of the musical fraternity. The jays are the noisiest; the cedarbirds the most silent. The most unsocial are the raven, the olive-sided flycatcher and his cousin, the wood pewee. The hardest fighters are kingbirds. The most ferocious is the goshawk. The most intelligent is the crow, and the least intelligent, night-hawks and spruce partridges. The most beautiful nests are made by humming-birds and wood pewees, and the worst by the cuckoos. The cow-pen bird makes no nest, but lays her eggs in the nest of other birds for them to hatch. The raven is most distinguished as a bird of bad omens. The only good thing I ever read about them is the account of them taking food to the prophet Elijah. They are so eager and greedy to eat all they can 
find that nothing short of a providential watching would prevent them from devouring the prophet's morsel.

An old fourteenth-century manuscript written in the English of that time relates in rude verse the raven's outgoing from the ark as follows :

"Then opin Noe his windowe

Let ut a rauen and forth he flew

Dune and up, sought here and thare

A stede to sett upon somewquar,

Upon the water sone he fand

A drinkled beste ther flotand

Of that fless was he so fain

To ship come he neuer againe."

Spenser, the old poet, tells us of

"The hoarse night rauen trump of doleful drere."

Shakespeare has it that the raven

$$
\text { "Tolls }
$$

The sick man's passport in her hollow bill, And in the shadow of the silent night

Doth shake contagion from her sable wings."

It was believed that the nestlings could be made into medicine, and here is the way to do it as given by Guillim, who wrote so long ago that his English may not be understood at a glance : 
"Take rauens bryddes all quyke onte of here neste and loke yot ye touche not the erth nor yot yei commen in none hous and brenne him in a neu potte all to powdir and gif it ye seke man to drynnke."

\section{Or in modern fashion :}

“Take raven's birds (young) alive out of her nest, and look that you touch not the earth nor yet come into any house, and burn him in a new pot, and give it to the sick man to drink."

"Any old thing" did for sick people in those days, and the custom clies hard.

Among the birds on my list the kingfisher is most pleasantly interwoven in myth and song and story. The old Greeks had it that Halcyone was a daughter of Eolus. Her husband was drowned in the Agean Sea and as she wandered on the shore she saw afar the dead body of her husband. The gods in pity changed her into a kingfisher, and her husband shared the same happy fate. Halcyon means brooding on the sea, and it was pretended that kingfishers made floating nests on the sea, and during fourteen days while the eggs were hatching the winds went down; and these were "Halcyon days." The older English poets often allude to this myth. Drayton has it thus :

"The haleyon whom the sea obeys

When she her nest upon the water lays." 
Dryden writes :

"Amidst our arms as quiet you shall be As halcyon brooding on a winter sea."

\section{Milton says :}

"While birds of calm sit brooding on the charmed wave."

The kingfisher of the myths is a very different fellow from the rough-and-ready, practical, every-day bird of that name. So far is she from nesting on the "charmed" sea that she digs a long tunnel in a bank and there the eggs are laid. As a family they are birds of fine feather, but their grating, loud voice is against them, with many, and there is no elegance of form. Their feet are deformed into palms for grasping a fish while eating it. Their bills are large and powerful, adapted to seizing the nimble and struggling fish, on which they depend altogether for food. When a kingfisher quits his perch by a river or brook side he always starts, and keeps up a clattering, horse-fiddle outcry, as if he desired to let everybody know of his coming. I do not object to his announcement; it fits him exactly, for he comes, low down and direct onward, like a feathered express. In fact, I am so far away from good taste in musical sounds that I am more moved by the loon's long midnight 
"holoo" across a lake than I am by the liquid notes of the hermit-thrush. Something that goes deeper with me is the whistling scream of the circling hen-hawk, as he mounts the dizzy spirals of the sky, than there is in the cat-bird's jocund song. I prefer the "Too, hoo, hoo" of the "boding owl" from his perch in the dark hemlocks, to the robin's evening lay. The owl starts the "goose-flesh" on me; it is as if some phase of the night side of nature had found a voice for itself. Even the muffled "honk" of wild geese at nightfall moved Bryant to write the finest poem in all bird literature. There is in it a loftiness of feeling and beauty of expression that place it in the first ranks of short poems. No melody of singing bird could have moved him like this wild cry, shouted down from the depths of the twilight sky by this flock of chartless and compassless voyagers.

To learn to like these voices and aspects of nature is to get more out of life that is worth having; to neglect them is to pass by the sources of true and healthy enjoyment. While such negligence may not be a sin, it is an ill-mannered reception of a princely birthright. "To consider the lilies how they grow, and notice that Solomon in all his glory was not arrayed like one of them," is not an idle sauntering by 
the way, but a becoming attention to the splendor of God. It is either a narrow mind, or a sadly neglected one, that never rejoicingly says to himself or another, "Lo the winter is past, the flowers appear on the earth, the time of the singing of birds is come, and the voice of the dove is heard in our land." 


\title{
MICMAC INDIANS.
}

\author{
"RUGGED type of primal man, \\ Grim utilitarian ; \\ Loving woods for hnnt and prowl, \\ Lake and hill for fish and fowl." - WhitTrer.
}

I HAD almost forgotten to say that our road 1 to the mines ran across an Indian reservation. After the white men had disposessed the red men of the lands they had owned for many centuries, then the generous Christian granted back again a small portion of his plunder. A few Indians have lingered on these acres well watered by streams and lakes, but his pale-face brothers come there by dozens to whip the waters for trout. Long ago the Indians bowed to the inevitable; resistance to the invaders became hopeless.

About three hundred and fifty years ago the French made the acquaintance of these people of the forest. That was their first introduction to Europeans. They were hunters and trappers and fishers. Not a single tool or weapon of metal could be found among them. They 
were not destitute of fine qualities, and received the white strangers with dignified hospitality. They were quick to see the advantages of muskets and iron axes over bows and arrows and stone tools. In all the province there were about four thousand Indians. They were well acquainted with the shores and the interior. They had named the harbors, and headlands and bays, and mountains and lakes, and could make maps oi the country and far outside to Quebec and New England. While they did not live in grand houses and make a great show in the world, still they were far from being a very low type of men and women. They had no law books, but there was an unwritten code demanding the observance of the common virtues of life. In the nature of things they could not live in large communities, for they did not till the soil to secure food. Certain families had their homes from generation to generation in the same district. Among themselves they led a quiet life, in some measure subject to a head man or chief of the tribe, who was chosen for some fitting qualities. The Mohawk Indians from the State of New York were an adventurous, fearless tribe, looking for scalps, and became a menace and terror to the Indians of Nova Scotia and what are now the 



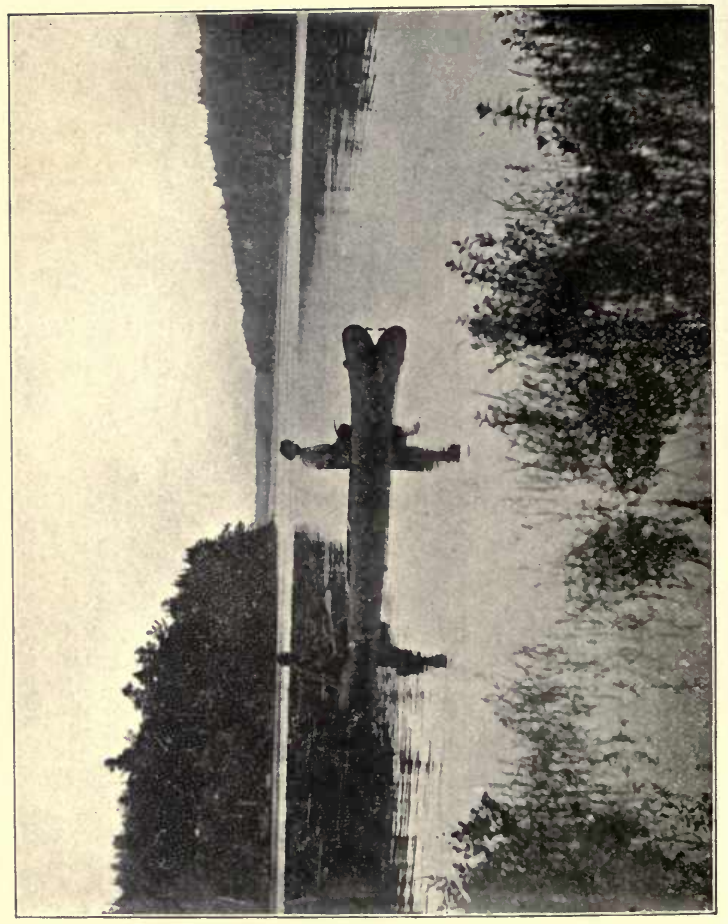


neighboring provinces. The French soon managed to be on good terms with the natives; they settled among them and traded with them, lived often in their wigwams and married their daughters. More than this, French priests came out and lived with them and learned their language, and converted them to their creed. This was not a difficult task, for the Indians believed in a good spirit who made all good things; in an evil spirit who was the author of all evil. They believed in a heaven and a hell, and also a middle state, or purgatory, says Father Vetromile. This was a long start in the right direction, and the devoted missionaries gathered them all into the Roman Church, where, as a rule, their descendants remain. Before their conversion they were very cruel in war, and afterward they perpetrated dreadful deeds, but white Christians were setting them no better example. In New England Eliot, Tupper and Mayhew were preaching to the Indians with a desire to save their souls, but all their work bore no great fruit. Eliot translated the Bible into their language, and I believe there is not a man who can read it, unless Father Vetromile be still alive. One may well doubt that it ever served the purpose intended. The New England white men who brought 
the Bible stole the Indians' belongings, sold them into West Indian slavery, and when they conquered and killed, in 1675, their leader, Chief Philip, they cut off his head, brought it to Plymouth and stuck it high on a pole where the skull rattled for generations over the heads of these pious savages. The wrens at last came to nest in this brain-box, wherein had been hatched many daring schemes before ever a wrenlet saw light there.

Rev. Dr. Rand, with great zeal and ability, mastered the Micmac language and translated and printed the New Testament, Genesis and Exodus, together with reading-books; and some Indians learned to read it, but they had no great inclination in that direction, not more than white people, and that is not much. Dr. Rand says that many of the Indians had not "so much as heard of the Bible," although they were all Christians by baptism. That Dr. Rand filled a long-felt need by furnishing them with the scriptures is not credible. They were evidently not greatly neglected by their own church, for even Dr. Rand said after he spent forty years in this work :

"I have never made it a special object to change their religion; I could not see the slightest advantage it would be to them." 
If he had taken that view of the matter at the outset he would never have entered on a mission to the Micmacs, and gone into an ecstasy of rejoicing when he had translated the first verse of scripture, as if the letter was much more than the spirit. The Micmacs were the first Indians north of Mexico to embrace Christianity, and their teachers were missionaries of rare zeal and piety, deserving of great praise for their self-denial and devotion to humanity.

In his later years, when his knowledge of Micmac language was thorough, Dr. Rand must have been both pained and amused over his crude translations made when his zeal outran his knowledge. Eliot, the famous New England missionary to the Indians, relates that when he was making his translation of the Bible, and came to Judges v: 28, "The mother of Sisera looked out at a window and cried through the lattice," etc., he was unable to find a word for lattice. He explained to his Indians that a lattice was a bit of wood-work made of narrow strips placed side by side, but not very close together. So they gave him a word, and he used it in the translation. Long afterwards he saw that the passage read thus, "The mother of Sisera looked out at a window and cried 
through the eel-pot." The fact is that an eel-pot as still made by the Micmacs is really a lattice-work in hoops, to allow the escape of the water, but not the eels, when it is set in a stream.

The Micmacs were a comparatively docile and gentle people, and the missionaries found the task of conversion much easier on that account. In New York State, where the Five Nations dwelt, an Indian confederacy, there was a stern opposition to the introduction of Christianity. Their great Seneca chief, Red Jacket, who died in 1830, was an eloquent pagan to the last. A missionary visited them, and they came together to hear him. Among other things, he told them "there was but one religion, and without that they could not prosper. They had lived all their lives in gross darkness, and, finally, if any objections could be made he would like to hear them."

To show how the matter looked to Red Jacket I introduce his famous speech, as it will at the same time give the reader a good idea of Indian argument and eloquence:

"Brother, you say you want an answer to your talk before you leave this place. Listen to what we say: There was a time when our forefathers owned this great land. Their seats 
extended from the rising to the setting sun. The Great Spirit had made it for the use of Indians. He had created the buffalo, the deer, and other animals for food. He made the bear and the beaver; their skins served us for clothing. He had caused the earth to produce corn for bread. All this he had done for his red children because he loved them. But an evil day came upon us. Your forefathers crossed the great waters and landed here. Their numbers were small. They told us they had fled from their country for fear of wicked men. They asked for a small portion of land. We took pity on them, granted their request; they sat down among us. We gave them corn and meat. They gave us poison fire-water in return. You have now become a great people and we have scarcely a place left to spread our blankets. You have got our country, but are not satisfied. You want to force your religion upon us. You say that you are sent to instruct us how to worship the Great Spirit agreeable to his mind; and if we do not take hold of the religion you white people teach we shall be unhappy hereafter. You say that you are right and we are lost. How do we know this to be true? We understand that your religion is written in a book. If it was intended for us as well as for 
you, why has not the Great Spirit given it to us? and not only to us, but why did he not give ourforefathers the knowledge of that book with the means of understanding it rightly? We only know what you tell us about it. How shall we know when to believe, being so often deceived by the white people?

"Brother, you say there is but one way to worship and serve the Great Spirit. If there is but one religion, why do you white people differ so much about it? Why not all agree, as you can all read the book?

"Brother, we do not understand these things. We are told that your religion was given to your forefathers, and has been handed down from father to son. We also have a religion which was givell to our forefathers and has been handed down to us their children. We worship that way. It teaches us to be thankful for all favors we reeeive, to love each other, and to be united. We never quarrel about religion.

"Brother, the Great Spirit has made us all. $\mathrm{He}$ has given us a different complexion and different eustoms. Since he has made so great a difference between us in other things, why may we not conclude that he has given us a different religion according to our understand- 
ing? The Great Spirit does right. He knows what is best for his children. We are satisfied. We do not want to destroy your religion or take it from you, we only want to enjoy our own.

"Brother, you have now heard our answer to your talk, and this is all we have to say at present. As we are going to part, we will come and take you by the hand and hope the Great Spirit will protect you and return you safe to your friends."

Red Jacket had a mind of his own, and clung to the old way of the fathers. It was his misfortune to come much in contact with the greed and intolerance of white men, and he could not believe in their religion.

The Indians of New England and the British maritime provinces were divided into many clans or tribes. In general appearance, customs and language they were much alike. The language did not differ more than English differed a century ago in England from shire to shire. The Inclians of Nova Scotia did not call themselves Micmacs, it was a nickname given them by the French. They were known as Souriquois. They were great believers in magic and witches, and Malike was an old name for witchcraft, and out of this word was derived Micmac. 
If the Indian had discovered iron, and learned how to change it into steel, a thousand years before America was discovered, he might well have made a name for himself among civilized nations. Their language was admirably calculated for all manner of literary purposes. It is not a rude, harsh, barbarous tongue, but smooth and soft, and immensely rich in words.

On this point Dr. Silas T. Rand says :

"The Micmac, like many, if not all, of the native American languages, is remarkable for its copiousness, its regularity of declension and conjugation, its expressiveness, its simplicity of vocables, and its mellifluousness; in all of these particulars and others it will not suffer in comparison with any of the most learned and polished languages of the world."

Dr. Rand was not only learned in Micmac but he was wonderfully acquainted with many other languages, including Greek and Latin. Our Indian, who thinks in his own speech and talks in English, makes a rather awkward attempt. The difficulty is this: he tries to translate the arrangement of his words into something equivalent in ours, but the whole structure and grammar of his language bear no resemblance to English; hence he makes such blunders as the following: 
"Long time ago, when first Indian makeum God."

Or this :

"Joe Williams his hogs my heelus (eels) eatem all up."

This is a language where the roots of words are all smoothly dovetailed into one another to form one long word, which is really a sentence. Here is such a word: Yăle-oole-maktāwe-pokŏse. This signifies, "I am walking about carrying a beautiful black umbrella over my head." The word is made up from other words, as follows: Yălea, I walk about; maktāuāre, I am black; welae, I am beautiful; pokuoson, a shelter over the head. The roots of all these words are easily discovered in the long word that is a regular verb in the indicative mood, present tense, first person, singular. As a sample of such long words, here we have one meaning "They are going to eat supper together": Najdejemouweoolowouadullaolteedussuneega. This wordbuilding is a very different thing from simply throwing whole words together, as if we were to write it in English thus: Theyaregoingtoeatsuppertogether.

A very much nicer arrangement is in the Indian speech. The speaker makes the long word when he needs it, and he does that by certain 
rules of construction, and he can express the nicest shades of meaning by the introduction of a single sound.

The older Indians had a good deal of pride in their language and aimed to speak it with propriety. When the French came amongst them, bringing many things they had never before heard of, then they either attempted to use the French name or they coined a new word; for example, they called the French Wenjoo, and they named cow Wenjooteam, meaning French moose, as Team is their name for moose. An apple they named Wenjoosoon, or French cranberry. The Indian name for horse is Taseboo; this is a mere attempt to use the French des chevaux. They had no oars, but used a paddle instead, which they called Thargan; so they named an oar French paddle: Wěnjootaāgan.

A slight change in the termination of a word enables the Indian to express a great variety of meaning. To illustrate, we will take the word for bear, Mooin; for bear's grease, Mooinōne; for bear meat, Mooinäwā; for bear skin, Mooinu; I am a bear, Mooināwe.

However barren of results Dr. Rand's work may have been from a religous point of view, it was well worth doing from other considerations. It is not for me to say that there were no good 
results ; evidently there were, but they were disappointing in their meagreness and not propor. tioned to the effort made to produce them. Through the long and difficult labors of Dr. Rand, the student of human history has a dictionary of their language, and a collection of their folk-lore tales, and many items of interest besides.

It is a prevailing notion that this tribe is disappearing, but the census shows a steady increase, thus: 1851 , there were $1.056 ; 1861$, 1,$407 ; 1871,1,666 ; 1881,2,125 ; 1892,2,157$.

It has been a very difficult task for the Indians to comply with the new conditions that the white man enforced upon them. From time reaching back thousands of years they had been liunters and fishers. Even as they walk on the streets and roads there is a soft yielding-at-theknee stealthiness of step that tells the story of their past life in the forest. 'To work the soil for a living is utterly foreign to their nature. In fact, to settle down in a place and remain there is contrary to their natural instincts as much as it would be to a wild goose. They can no longer live by hunting, and even white men, as a rule, in Nova Scotia find that farming needs a good deal of piecing out to yield a living. The Indians have given up their bark wigwams, their 
bows and arrows, and moccasins and blankets, and now cling to the outskirts of the white man's towns and villages, living for the most part in huts, and using their mechanical aptitude in coopering, canoe-building and basket-making. They act as guides to hunters and fishermen, and in these various ways, with a little planting, manage to live in a manner not well calculated to make the best of them. They are a quiet, orderly people, very hospitable and unselfish with one another.

The Indian family on the Molega Road consists of a widow, "Kate Jeremy," and her married son and child, and an unmarried son. They live in a snug, clean cottage, have quite a farm, keep oxen and a horse, are very industrious, sober people. Even with them the old ingrained tendencies and dispositions crop out in their canoe-building, moose-hunting and fishing - occupations that demand some of their time.

What the future of this tribe will be it is difficult to tell with certainty ; but one may be sure that they will not come into close competition with the whites in any trade or business; most probable that they will long continue to exist as a separate people, retaining their language but losing their peculiar customs. They are not long-lived, and a large proportion of them die 
young. Consumption carries away many of them. Strong drink has proved a great curse to them, in even a greater degree than to white men. They have taken kindly to the white man's vices, and his virtues of steady industry and thriftiness have been largely neglected. Although they live in houses and cook on stoves, and sleep on bedsteads and sit on chairs, and wear our cut of garments, still they are born children of the forests, and all their dispositions and aptitudes go back to the old conditions of the rude hunter life of their forefathers.

The question is often asked, From whence came the Indians? A great deal of study and laborious research has been given to the matter, but as yet there is no sure answer. It is most probable that they originally came from Asia, entering in the vicinity of Behring Straits. Their faces, complexion and language favor this view. The indications are that they were not the first people who lived on this Continent. 


\section{PUFF-BALLS, TOADSTOOLS AND THAT SORT OF THING.}

"THE grisly toadstool grown there mought I see
And loathed paddock lording on the same." - SPENgre.

T WANT to say a word for these overlooked, 1 half-despised commonplaces of nature. "Puff-balls" are known on sight by all frequenters of fields and pastures and rural roadsides. Country boys find some amusement in squeezing the "smoke" out of them. They are looked upon as things that grow without seed or root, but come up at night in a hurry, wherever they will. In England they were long regarded as something not good. A common name for them is the "Devil's suuff-box," also "Puck's fist" or "Puck-ball" — and Puck here is only another word for "Old Fellow."

So far is this dainty thing from being a "Devil's snuff-box" that it is a veritable casket of wonders. It would require a large book to explain and illustrate them all, but we will call 
attention to some of them. In the first place, let it be understood that this puff-ball is one of the great Fungus family, wherein are all toadstools, mushrooms, mildews, black-knot, potato-blight, rusts, etc.

The puff-ball is not a freak of nature, but the seed-vessel of a low order of plants. When it first appears as a small solid ball breaking through the soil then the real plant may be found running in white threads through the ground. These grow with great rapidity, and at the proper time they put out into the light this tiny globe, that is fed from the roots and grows with astonishing vigor and rapidity. In four or five days it has reached an inch or two in diameter, changed inside from a clear white pulp to a sack of purple-brown powder. It has shrivelled up at the base, burst open at the top, broken away from its anchorage, become the sport of the winds, breathing from its tattered chimney little clouds of dust, until decay finishes its existence. All this has a meaning. There is method in it from start to finish, and it is the privilege of the human mind to investigate and understand it, in a measure at least. If we breathe on a bit of glass and then force the smoke of the puff-ball against it till there is a little cloud on the glass, and place it under 
a microscope of fairly good power, we shall see that this dust is altogether made up of regular-shaped bodies with little tails to them. Under very high magnifying instruments and in skilful hands these little bodies are found to be a naked kind of seeds with no embryos, called spores, and the tail is really a wing; and a common puff-ball as large as a small apple contains not less than ten millions of these seeds, and every one of them would grow if it had a favorable opportunity. The fact that there are so many indicates the difficulties of getting a footing in the world. The living organism under ground, the mycelium, pushes this little globe outside and stuffs it with millions of seed spores, all winged for the air, fills it with gases till it bursts away an opening for them to escape, cuts it off from its rootage, that the winds may sport with it and thus the seeds be sown far away from the grounds already occupied by its kind. The human mind cannot conceive or in any way adequately comprehend the energy and intelligent action in that little ball, that within a few days brought forth so many millions of spores, so minute that the naked eye cannot see them, only as dust or smoke, and yet so made, that once lodged where soil, and moisture, and heat, are 
favorable, each one will become the centre of such living activities that all about it the earth will respond to its call and myriad million atoms will come trooping to its demand in order that it may grow and furnish other "puff-balls" while the earth endures. The sun is a globe fourteen hundred thousand times larger than this earth, and we know something of its substance, and the dimensions are very great, and nations have worshipped it as the fountain of light and the giver of life; but, after all, one may find in this little gray-skinned ball the evidences of vital powers intelligently fashioning in a few hours more of these wonderful seeds than there are stars within the whole range of the best telescope! The human mind is startled and amazed in the presence of such microscopic marvels, and the right-sky, lit with many million suns, as it surely is, does not demand a grander cause for its existence than this tiny sphere at our feet, stuffed with millions of living germs wherein are held the latent forces that will reproduce their kind when opportunity offers.

I make such comment as this because I am persuaded that the supreme benefit of all natural-history studies lies in their power to arouse the faculties to considerations that take hold on 
realities that outrank the material objects that suggest them.

We have at least two common species of puff-balls. One is brownish-white, with a short stem, and somewhat pear-shaped and warty; this is the Lycoperdon gemmatum. The other rests close on the ground, is white, and a little warty; this is the Lycoperdon saccotum. They are both good food when properly cooked and plucked in season. They should be gathered when fresh, while the inside is pure white, cut in slices and fried in butter. Many good judges of such things prefer them to eggs.

Now we will take up another branch of this Fungus family. The toadstools are known to all who "take their walks abroad." There is one group or family of which there are many members common all about us. These are the Agarics, and the common mushroom of the table and market belongs here. They are shaped like an umbrella. On the under side of the cap, or pileus, are the gills, arranged around the stem, like spokes of a wheel. When it is just showing itself through the earth it is a tiny ball, but if we eut it in halves the indications of the umbrella-shape will be seen. When fully out of the soil there is a thin veil drawn over the gills, and it soon breaks, and shrivels up 
around the stem, and remains a good mark of this family of Agarics. The toadstools are but the seed-bearing organs of this cellular cryptogamic plant, that flourishes in the dark soil in the form of rootlets and threads. The spores, or seeds, are formed in the gills by millions and continually shed, but we do not see them, and the lightest breath of air carries them away. However, it is an easy matter to get a view of them in this way: slice off the cap and carefully place it on a bit of black paper, or even brown, and cover it over with a dish, and let it remain for a few hours. Upon examination you will find that the spores have dropped upon the paper, forming a beautiful wheel as each gill threw down its own portion directly under it. In some species the spores are dazzling white, in others pink, in others golden; but in all, when under a good microscope, can be seen beauty and elegance of finish, as if each one was the pride of some master eye and hand. These wheel patterns are so beautiful that one may preserve them for the pleasure of looking at them. This is easily done by gumming the paper with a little mucilage and allowing it to dry, and placing on the top of the specimen a piece of damp cloth; this will yield enough moisture to make the paper slightly sticky, 
and the spores will be fixed where they fall on it.

The general impression is that toadstools are poisonous when eaten, but the charge is ton sweeping. There are about two thousand species known and described. Out of that number less than fifty are believed to be poisonous, and the others are good food and very largely eaten. In Russia, especially, almost all kinds are freely eaten. In this province there is the "deadly Aminita." To make matters worse, this is closely related by family ties to the edible mushrooms. The resemblance has been the death of many people, who were deceived by appearances, and ate the poisonous fraud. It is of a medium size, with a yellow-russet or pale-yellow eap, and $a$ white stem and gills, and when full grown has a shrivelled veil furled about the stem. At an earlier growth the veil covers the gills. The distinguishing mark that brands it as dangerous is not always, nor often, in sight. The stem rises out of a little cup with ragged edges: this is the sign; have no further acquaintance with it, for even the smell of it is sickening to some persons. We have another that must not be eaten. It is known as the Fly-blow agaric, and one may find them in abundance - a large stout species, with a reddish or even red and 
yellowish cap, well covered with white warty particles, resembling "fly-blows"; this is not considered fatally poisonous, and in some countries it is freely eaten, after a treatment with salt. The natives of Siberia and Kamschatka manage to get drunk on this species, and as all other intoxicants are very scarce, and they prefer very often to be drunk rather than sober, they consequently hold this species in great esteem. I have often noticed that our cattle in the autumn, when there is a good crop of toadstools in the woods, and they get a taste of them, become almost crazed for more, and if allowed to range at large will make a bee-line for the place where they grow. They seem to prefer a very large white species, and I never heard of any bad results to them or to those who drank their milk. Our red squirrels eat freely of a small red mushroom of the Agaric family. One may often see them scampering away with a lunch in their teeth.

The bracket fungus, that grows out from the sides of trees and logs and stumps, is often more than a foot across. It is arranged on a different plan from toadstools: there are no gills, but on the under side there are innumerable holes running up through the latest annual growth; they are as smooth as rifle barrels. The spores are 
formed at the upper ends, and shot like bullets into the air. Once I had the good fortune to see this process in full operation. The fungus grew on the side of a stump in the woods; I chanced to take a rest on the other side, and a glint of sunshine fell across the bracket, that I could not see from my position, but what I did notice was regular pulsations of brilliant, glistening particles, forming little puffs, like steam, as they drifted across the sumbeam and vanished instantly in the common daylight. Before looking for the cause I guessed rightly that it was a fungus sowing its spores by the tens of millions, and they were carried away on the summer air. The pulsation, or rhythmical action, must have been in the mechanism of the object itself, - all its little guns fired at once.

It would be "o'er long a tale to tell " of the various forms taken by these things. They produce the dry-rot of timber, the "punk" of pines, the touchwood of the yellow birch. They attack dead trunks and limbs and help to reduce them to their elements. Hardly a living species of animal that does not suffer from this great fungus tribe. They particularly seize upon insects of many kinds, entering their bodies by various channels. Once there, the spore germinates and grows, at the expense of 
its host. Death is the certain result. Our house-flies come to grief in this way, and the pity is that more of them did not meet with a like fate. We may often see them on neglected window panes, dead or dying in the centre of a whitish cloud, this cloud is made of mildew threads. After filling the body of the fly they grow and flourish outside - a purely fungus growth from a mildew spore lodged in the insect. Caterpillars in various parts of the world are carried off in this way. In Australia one may see living caterpillars crawling with a stalk of fungus, more than an inch in height, growing from the head, and sure to kill. Of this fungus group, by some lines of relationship, are the microbes and bacilli that are the causes of diphtheria, consumption, fevers, cholera, and most other diseases of men and beasts. We literally have to contend with powers of the air, an invisible host of living cells that enter our lungs at every breath, flourish in our blood, colonize in our muscles and bones and teeth, and there multiply by growing and breaking in pieces. Without mouths they eat, without stomachs they digest, without organs of generation they multiply by myriads in a day. If it were not that some feed on other kinds we would fare worse than we do. To have lived 
at all amid such enemies is a marvel in itself; and if it were not that most of them do us no harm and some of them help us, the end of mankind could not be far away. This is at first glance a long bit away from puff-balls, but my text added " and that sort of thing."

Here, then, is a brief essay on a subject deserving attention, and my only hope is that some reader will be stimulated to study in this promising and delightful field. Indeed, I may say in this closing sentence of my little book, that the object nearest my heart in writing it has been to arouse in some small measure an enthusiasm for out-of-door studies, that are so full of health and happiness, with ever-widening visions of nature and life. 



\section{THE LIBRARY \\ UNIVERSITY OF CALIFORNIA \\ Santa Barbara}

\section{THIS BOOK IS DUE ON THE LAST DATE STAMPED BELOW.}


UC SOUTHERN REGIONAL LIBRARY FACILITY

A $001294886 \quad 5$ 
